
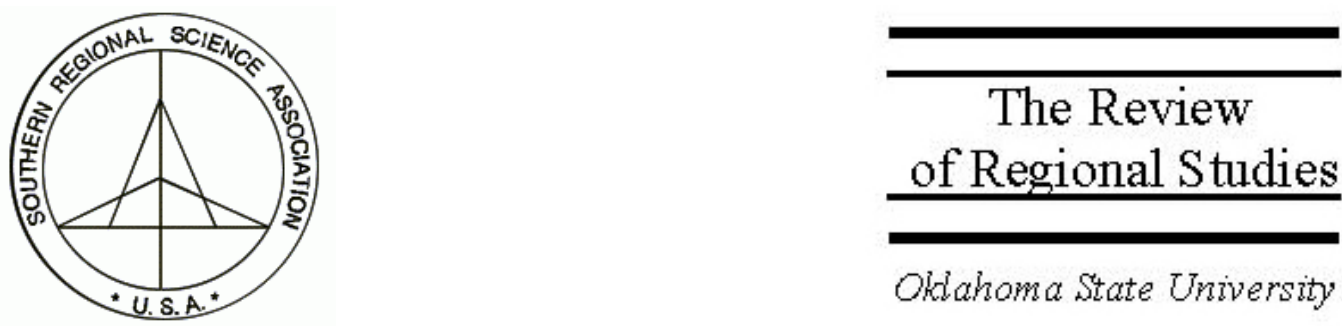

Oklahoma State University

\title{
Explaining Geographical Differences in Water Prices: Do Institutional Factors Really Matter?
}

\author{
Suho Bae \\ Department of Public Administration, San Francisco State University, Downtown \\ Campus, 835 Market Street, $5^{\text {th }}$ Floor, San Francisco, CA 94103, e-mail: bae@sfsu.edu
}

\begin{abstract}
The availability, price, and quality of infrastructure services vary considerably across regions. This paper analyzes which elements significantly contribute to geographical differences in water prices. For empirical analysis, it employs water supply price and demand equations under a system of simultaneous structural equations. Several institutional factors explain geographical differences in water prices, such as prior appropriation water rights versus riparian rights, pricing structures, combining water bills with other bills, and other infrastructure. Water rate regulations by public utility commission also have some negative effects on water prices. State environmental regulations and commitments contribute to higher water prices, especially for non-residential water users.
\end{abstract}

Keywords: Infrastructure services; Water prices; Institutional factors; Structural equation system JEL classification: Q25; Q28; C31

The author would like to thank Michael I. Luger, Robert H. Wilson, Thomas L. Gais, and anonymous referees for their helpful comments and suggestions on an earlier draft. 


\section{INTRODUCTION}

Infrastructure services affect social welfare in two important ways (Kessides 1996; Haughwout 2001): by facilitating private sector business activities and by improving quality-of-life environments. Some services, like water and power, are used as direct inputs in the production process while others improve general productivity or reduce labor costs. Manufacturing plants, for example, generally use water for fabricating, processing, washing, diluting, cooling, or transporting a product; incorporating water into a product; or for sanitation needs within the manufacturing facility (Hutson et al. 2004).

That infrastructure investment has been one of the most important regional development strategies (Hirschman 1958) demonstrates the importance of the infrastructure service role in regional economic development. ${ }^{1}$ Throughout U.S. history, all levels of government, particularly state and local, have been actively involved in infrastructure investment to gain a competitive advantage over other jurisdictions by recruiting new businesses and inviting people into their own jurisdictions (Tarr 1984, 1985). ${ }^{2}$

The contributions of infrastructure services to quality-of-life environments are as important as economic development contributions. ${ }^{3}$ People around the world, particularly in developing countries, suffer from inferior or unavailable infrastructure services. Access to clean water and sanitation is crucial for reducing morbidity and mortality, yet approximately one billion people do not enjoy clean water and almost two billion lack accesses to sanitation services (World Bank 1994).

Water prices vary considerably across localities and regions. As shown in Table 1, in 2004, average monthly water charges per 100 cubic feet (Ccf) for non-residential users were $\$ 1.52$ and varied from $\$ 3.70$ per Ccf in the Dare County, North Carolina, to $\$ 0.26$ per Ccf in Idaho Falls, Idaho. ${ }^{4}$ Table 1 lists the highest and lowest water prices of 259 water utilities.

Existing literature has examined the determinants that facilitate privatization in providing local infrastructure services (see, e.g., Bel and Miralles 2003; Joassart-Marcelli

\footnotetext{
1 In spite of extensive research on the relationship between infrastructure investment and economic development since Aschauer's 1989 article, there is still no general consensus about that relationship.

2 Taking water services as an example, in the mid-1750s, the city of Philadelphia purchased private pumps and provided water services to customers; by 1771, the city owned 120 out of a total of 498 pumps. The city of New York encouraged new well construction through subsidies and provided funds for well repair, cleaning, and construction through a statewide tax in the late 1780s and 1790s (Tarr 1985).

${ }^{3}$ Few empirical studies on the contributions of infrastructure services to quality-of-life environments are available, which reflects the difficulty of measuring those contributions (Haughwout 2001).

${ }^{4}$ Monthly water charges per $\mathrm{Ccf}$ are calculated as the dollar amounts per $\mathrm{Ccf}$ charged monthly to non-residential users when they consume $500 \mathrm{Ccf}$ per month.
} 
TABLE 1

Monthly Water Charges per Ccf, 2004

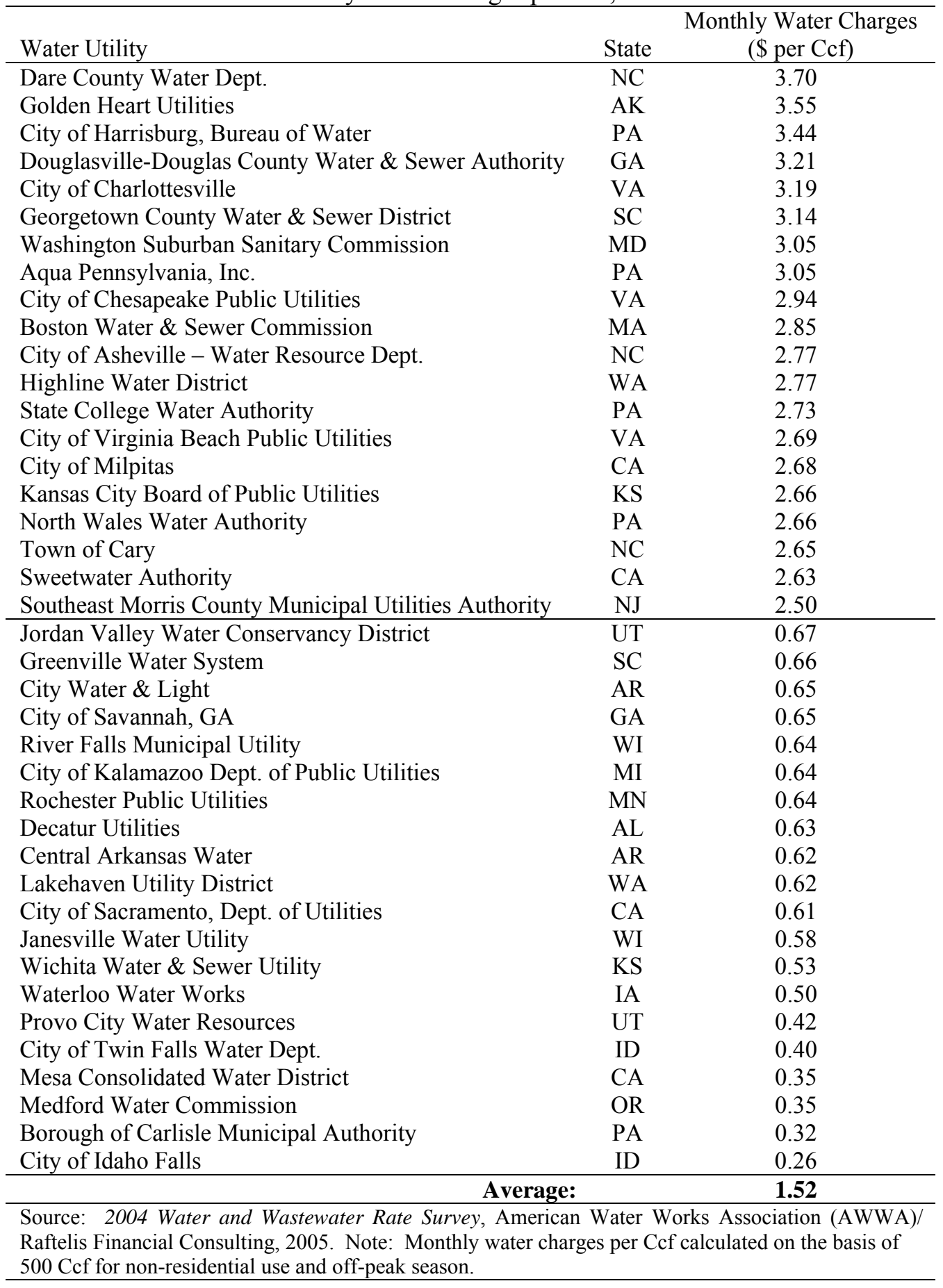


and Musso 2005; Walls, Macauley, and Anderson 2005). The effects of private ownership and operation on the price and quality of local services are interesting, and this paper examines water supply as its example. It also investigates what other institutional factors and characteristics are important in explaining geographical differences in water prices, such as pricing rate structures, prior appropriation water rights (versus riparian rights), seasonal peak rates, and water rate regulations.

Section 2 develops a conceptual model to explain water price differences by using the price equation for water supply along with its demand equation under a system of simultaneous structural equations. Section 3 presents an empirical model of water supply. In Section 4, variables are defined and described along with descriptive statistics. Section 5 presents empirical findings. For empirical analysis, the three-stage least squares (3SLS) estimation technique is utilized to avoid the simultaneity bias that can be caused by the ordinary least squares (OLS) estimation of both demand and price equations, and to account for potential residual cross-correlation across equations (Zellner and Theil 1962; Kennedy 2001, pp. 166-167). Section 6 summarizes empirical findings and discusses study limitations.

\section{CONCEPTUAL MODEL OF THE DEMAND AND PRICE EQUATIONS FOR WATER SUPPLY}

To develop a conceptual model of what elements are important in explaining geographical differences in water prices, the price equation needs to be understood along with its demand equation under a system of simultaneous structural equations (Halvorsen 1975; Merrett 1997; Renwick, Green, and McCorkle 1998; Barkatullah 2002). ${ }^{5,6}$ The general form of the demand equation for water supply in a water utility can be written as:

$$
Q=f(P, X, u)
$$

where $Q$ is the quantity of water demanded, $P$ is the price of the water supply, $X$ is a vector of the relevant exogenous variables that influence the quantity demanded, and $u$ is an error term. Here $P$ is endogenous, as is suggested in microeconomic theory. $X$ includes household size, median household income level, number and concentration of manufacturing plants with heavy water use, regional output level, population density, size

\footnotetext{
${ }^{5}$ Prices of some infrastructure services such as electricity, natural gas, water supply, and wastewater treatment are regulated by state agencies. But they set prices on the basis of marginal cost. Therefore, price setting for infrastructure services could be understood in the context of supply and demand. In other words, when state agencies set prices, they consider demand for infrastructure services, the costs of providing them, supply capacity and constraints, and so on.

${ }^{6}$ Here, the supply for water is assumed to be fixed. This assumption seems reasonable, because water utilities generally cannot expand (or reduce) their supply capacity for service production and delivery instantly in response to a sudden increase (or decrease) in the demand for water. In addition, an increase in the supply for water may not necessarily lead to an automatic increase in the demand for water. But still the omission of quantity of water supplied in a simultaneous-equations model may cause an omitted variable problem.
} 
of population served, and demand-side management policies and practices (such as water use restrictions, public information campaigns, and subsidies to encourage the adoption of more water efficient technologies) (Renwick, Green, and McCorkle 1998; Barkatullah 2002).

The general form of the price equation for water supply in a water utility can be written as:

$$
P=g(Q, Z, v)
$$

where $Q$ represents economies of scale where the water supply cost per unit decreases as the quantity of water demanded increases. (It should be noted that "water prices" are different than "water supply costs." Water prices are the charges that water users pay in return for water consumption while water supply costs refer to the operational, maintenance, and delivery costs in a water supply system. If a water utility does not fully incorporate operational, maintenance, and delivery costs into its pricing decisions, economies of scale may not be reflected fully in water prices.) $Z$ is a vector of the relevant exogenous variables that affect price decisions and contribute to geographical differences in water prices; ${ }^{7}$ and $v$ is an error term. There are four major categories of exogenous variables in the price equation: (1) institutional arrangements and characteristics of a water utility, (2) government regulations at the state and local level (including environmental, health, and safety regulations), (3) supply factors and characteristics, and (4) natural environments and local characteristics (including natural endowments and physical geography).

The first category includes whether a water utility is located in a state with a prior appropriation (DPA) or riparian rights doctrine, the size and ownership of the water utility, its pricing rate structures, seasonal peak rates, monthly late charges, mandatory connection ordinances, provision of other infrastructure services, and financial capacity. These differences across water utilities affect regional water prices. No water rights system exists at the national level, and water rights systems in the west differ from those in the east. Most eastern states (except Mississippi) follow the riparian doctrine. These states have a richly available water supply compared with western states. Riparian water rights are based on land ownership; and owners whose lands are contiguous to rivers, streams, ponds, or lakes have equal rights to use water from that source. This system was developed under the European legal tradition. Riparian water rights cannot be lost through non-use (Bureau of Land Management 2007; Shaw 2005, pp. 15-18).

Most western states (except Hawaii) follow the prior appropriation doctrine--"first in time, first in right" - as a response to water scarcity. There are five general characteristics of the prior appropriation doctrine. (1) The first appropriator on a water source has exclusive rights to use all the water necessary to fulfill his water right. A junior appropriator is

\footnotetext{
${ }^{7}$ In particular, supply factors and characteristics in the price equation may reduce the problem of an omitted variable (i.e., quantity of water supplied).
} 
not allowed to use his water right if it injures the senior appropriator. (2) A prior appropriation water right is justified conditional upon beneficial use. Beneficial use is a legal device to prevent the senior appropriator from wasting scarce water meant for use by later appropriators. (3) A prior appropriation water right is allowed on non-riparian lands as well as riparian lands. (4) A physical diversion of water is allowed for a prior appropriation water right. (5) An appropriative water right is dependent upon continued use of water and may be lost through non-use for a certain period (Bureau of Land Management 2007; Gopalakrishnan 1973; Shaw 2005, pp. 19-20).

Currently, 31 states follow the riparian doctrine exclusively, nine states follow the prior appropriation doctrine exclusively, and the other ten use a hybrid of both systems. ${ }^{8}$ Unlike riparian water rights, appropriative rights generally can be bought and sold; and all else being equal, water prices are expected to be higher under the DPA system than under the riparian rights system, as water rights prices are incorporated in water prices.

Water supply services are provided by either a public water system (city, county, or water district) or by a private water system. ${ }^{9}$ It is generally argued that privately owned water utilities perform better than those that are publicly owned from at least three theoretical perspectives: principal-agent theory, property rights, and public choice. Renzetti and Dupont (2004) explain the relationship between the ownership and performance of water utilities from each perspective. According to these theoretical foundations, public water utility managers do not necessarily have the incentives to improve the quality of water supply services and to lower costs compared with their private counterparts. From the principal-agent theory perspective, owners of public water utilities find it difficult to monitor public managers' behavior due to asymmetric information and uncertainty. From the perspective of the property rights theory, unlike owners of privately managed water utilities, public water utility owners do not have a strong personal motivation to improve performance, monitor managers' behavior, or provide managers with incentives. And, from the perspective of public choice theory, public managers have their own interests, such as maximizing their budgets and numbers of employees. However, in spite of these theories, there is little empirical evidence to support the theory that private ownership outperforms public ownership (see e.g., Bruggink 1982; Feigenbaum and Teeples

\footnotetext{
${ }^{8}$ Nine states with the system of exclusive DPA rights are Alaska, Arizona, Colorado, Idaho, Montana, Nevada, New Mexico, Utah, and Wyoming. Ten states with the mixed system of DPA and riparian rights are California, Kansas, Mississippi, Nebraska, North Dakota, Oklahoma, Oregon, South Dakota, Texas, and Washington. The other 21 states use the exclusive riparian rights system (Shaw 2005, p. 20).

${ }_{9}^{9}$ Public water systems are responsible for providing water to over 258 million customers in the U.S., which constitutes about 81 percent of the population. Private water companies own about 70 percent of American water systems, but they are small and often operate in rural communities (Hobbs 2003). Large foreign companies - in particular, French and German companies such as Suez, Veolia, and Thames/RWE-dominate the private water systems in the U.S. For example, Veolia and Suez have obtained billion-dollar contracts in several of America's largest cities, including Atlanta and Indianapolis. Suez owns United Water and U.S. Water LLC, Veolia owns United States Filter Corp., and Thames/RWE owns American Water Works (Hobbs 2003).
} 
1983; Teeples and Glyer 1987; Shih et al. 2004). Although these theories favor private rather public ownership, local governments - including cities, counties, and water districts - often directly provide water services to customers instead of contracting with private water companies. One possible reason for this is that water services are traditionally characterized as naturally monopolistic and are coupled with the high fixed costs in waterworks projects such as dam construction, water treatment facilities and water delivery systems, and have low variable costs.

Another reason stems from U.S. history. Private water companies could not expand their limited capacities in response to the dramatic urban population growth in the late eighteenth and early nineteenth centuries because waterworks required huge capital expenditures during their initial stages. This caused huge problems in water quality and availability. Private companies refused to provide water to the urban poor, mainly because of their inability to pay the fees. Private companies also refused to provide water for fire protection, street cleaning, and pollution elimination. Low quality water caused serious public health problems in cities. Cities and states developed public water systems as an economic development strategy for recruiting people and businesses to their jurisdictions. (For more details, see Tarr 1984, 1985, and Bae 2005).

The effect of ownership on water prices is more complicated to measure than its effect on water supply costs for several reasons. First, water prices may not completely reflect the operational, maintenance, and delivery efficiency of water utilities. Additionally, price setting may be more closely tied to revenue in private ownership than in public ownership. Private companies may find it easier to raise water prices than public utilities, as public utilities may be more concerned about the high price of water than minimizing operational, maintenance, and delivery costs. ${ }^{10}$ Thus, governments may subsidize public water utilities from other revenue sources like their general funds and charge water users lower prices to avoid criticism and the potential political fallout due to high water prices. In contrast, privately managed water utilities may be able to balance costs and revenues, even with water rate regulations. Therefore, the effect of ownership on water prices is hard to predict without empirical analysis.

Of further interest are the effects of different types of public ownership (city, county, or water district) on water prices. Water utilities under city ownership are more closely affiliated with their constituents and are more likely to be influenced by special interests

\footnotetext{
${ }^{10}$ The theoretical arguments suggest that public water utilities may be less concerned about costminimization than private utilities. See Renezetti and Dupont (2004) for more theoretical discussions on the relationship between ownership and performance of water utilities.
} 
and growth machines ${ }^{11}$ than under any other form of ownership, including private ownership. Therefore, they may have stronger incentives for lowering water prices than their counterparts.

Water prices also may be affected by different pricing mechanisms such as increasing or decreasing block rates, uniform rates, flat fee rates, time of delay pricing, water surcharges, and seasonal peak rates. Under uniform rates, water users pay a fixed price per Ccf. Under increasing or decreasing block rate structures, the price of water supply per Ccf varies depending on the total amount of water consumed (Renwick, Green, and McCorkle 1998; Barkatullah 2002). Some water utilities levy connection and development fees, minimum monthly charges, and monthly late charges. They also provide special subsidies (or tariffs) to water users or have mandatory connection ordinances.

Some water utilities provide other infrastructure services such as wastewater collection and treatment, electric services, solid waste collection and disposal, and natural gas services in addition to water supply services. When utilities provide other infrastructure services, they may be able to share personnel, machines, buildings, and equipment and may not need much additional investment to provide these services. This may also lead to lower water prices. But if utilities transfer all or part of other services' costs to water supply, then these are not necessary for lowering water prices.

State and local government regulations may affect water prices. As the AverchJohnson effect (1962) suggests, service providers under regulatory constraint may not try to match the marginal rate of factor substitution with factor ratios, which would result in higher production and service delivery costs. State and local governments are responsible for all types of infrastructure services, regardless of whether those services are provided by the private or public sector. Federal agencies like the Environmental Protection Agency (EPA) and the Federal Communications Commission (FCC) set standards and regulations for the price, quality, provision, and management of infrastructure servicesincluding water supply-which are enforced by state and local governments through cooperation with federal agencies. Some state and local governments also set additional standards and regulations on those services. ${ }^{12}$ Thus the cost, quality, and availability of infrastructure services are closely related to government regulations, even though the

\footnotetext{
11 "Growth machine" generally means that local business elites, along with government officials, are united to promote local economic development through, e.g., urban (re-)development projects and business subsidies and tax incentives for industrial and commercial recruitment and expansion. The growth-machine coalition influences specific policy decisions in promoting local development. Local business elites who make their fortunes through and have practical interests in local development and economic growth are, e.g., property owners and investors, savings and loan officials, lawyers, realtors, and local newspapers (Molotch 1976; Molotch and Logan 1984; Schneider 1992).

${ }^{12}$ For example, private contractors or companies are the major providers of communications/telecommunications services, but they are highly regulated and controlled by state regulatory agencies in terms of, e.g., price, requirement of universal services, and competition.
} 
degree of government regulation varies across types of infrastructure services. ${ }^{13}$ Water supply services are subject to varying degrees of government regulations across states and localities. High environmental standards and regulations at all levels of governments can impose a financial burden on utilities to satisfy clean water standards.

Supply factors and characteristics can affect water prices, including the maximum capacity of water production and treatment; water sources; and water loss during water production, treatment, and delivery. For example, water prices may be affected by how heavily a water utility relies on different water sources (i.e., groundwater, surface water, and water purchased from other utilities). Since groundwater is generally cleaner than surface water, less treatment is required before water is delivered (Renzetti 2000). This may translate to a lower water price. However, the cost of pumping groundwater can be higher than treating surface water, which then may lead to higher water prices for groundwater (Renzetti and Dupont 2004). When a water utility purchases large quantities of water from other water utilities, it imposes a higher price than it would otherwise. But as Renzetti and Dupont (2004) note, the price of purchasing water from regional water wholesalers may not reflect the true opportunity costs of purchasing water, in which case water prices may be lower than using either groundwater or surface water.

Finally, natural environments and local characteristics may include the availability of raw water, temperature, precipitation, physical geography, and median household income. For example, water is more available in wet regions than in dry regions. Thus, water prices are likely to be higher in dry regions than in wet regions.

\section{EMPIRICAL MODEL OF PRICE DIFFERENCES IN WATER SUPPLY}

From Equation (1), for empirical analysis, the demand equation for water supply can be written as:

$$
\begin{aligned}
& \ln Q_{i}=\alpha_{0}+\alpha_{1} \ln P_{i}+\alpha_{2} \ln S E R V P O P_{i}+\alpha_{3} \ln \text { POPDENS }_{i i} \\
& +\alpha_{4} \ln A_{C C T_{i}}+\alpha_{5} R S T R C T+\alpha_{6} E N V_{i}+\alpha_{7} D P A_{i}+\sum_{l=1}^{5} \varphi_{m} R G_{i}^{l}+\mu_{i}
\end{aligned}
$$

where continuous variables are in the natural logarithmic form, which allows the interpretation of coefficients as elasticities. Here, elasticity represents the percent change

13 That degree also varies across localities and states because the demand for infrastructure services depends on varying levels of economic development and there are cultural and historical differences in the level of regulation of infrastructure services. As Wagner's law suggests, the demand for public expenditure and investment increases as per capita income grows (Singh and Sahni 1984; Anwar, Davies, and Sampath 1996; Park 1996; Ansari, Gordon, and Akuamoah 1997). Thus, the demand for infrastructure services increases along with economic development in a region - in particular, the demand for environmental infrastructure services such as clean water supply, wastewater treatment, garbage collection, hazardous waste removal, and air pollution control. 
of water sold in response to a one percent change in an explanatory variable such as water price. $Q_{i}$ is the total 100 cubic feet $(\mathrm{Ccf})$ of water sold in water utility $i$ in which both components of water demanded (consumptive and diverted) are combined. ${ }^{14} P_{i}$ is the monthly water charges per Ccf in water utility $i$; $S E R V P O P_{i}$ is the size of population served by water utility $i$; POPDENS $S_{i}$ is the number of people per square mile, ${ }^{15}$ measuring population density in water utility $i ; A C C T_{i}$ is the size of water accounts in water utility $i ; R_{S T R C T}$ is whether water utility $i$ restricts water use (dummy); $E N V_{i}$ is the degree of state environmental regulations and commitments in water utility $i$; and $D P A_{i}$ represents whether water utility $i$ is located in a state with DPA rights or riparian rights. Five regional dummies are employed to control for other unexplained factors not included in this equation: Middle Atlantic, Midwest, New England, South, and West. The Southwest region is used as the base category for these dummies. $\mu_{i}$ is an error term with zero mean and constant variance.

From Equation (2), the price equation for water supply for empirical analysis can be written as:

$$
\begin{aligned}
& \ln P_{i}=\beta_{0}+\beta_{1} \ln Q_{i}+\sum_{j=1}^{7} \phi_{j} I N S T_{i}^{j}+\sum_{k=1}^{5} \varphi_{k} S U P P L Y_{i}^{k} \\
& +\sum_{l=1}^{2} \eta_{l} E N V_{i}^{l}+\sum_{m=1}^{5} \gamma_{m} R G_{i}^{m}+v_{i}
\end{aligned}
$$

where continuous variables are in the natural logarithmic form, which allows the interpretation of coefficients as elasticities. Here, elasticity represents the percent change of water price in response to a one percent change in an explanatory variable such as water sold. The price equation employs seven variables representing institutional arrangements and characteristics of water utility $i\left(I N S T_{i}\right)$. SUPPLY $Y_{i}$ represents five variables that account for supply factors and characteristics in water utility $i$, and $E N V_{i}$ represents two variables accounting for water rate regulations and the degree of state environmental regulations and commitments in water utility $i$. Five regional dummies (Middle Atlantic, Midwest, New England, South, and West) also are employed to control for other unexplained factors not included in the price equation; and $v_{i}$ is an error term with zero mean and constant variance.

Equations (3) and (4) are estimated by the three stage-least squares (3SLS) method to avoid the simultaneity bias that can be caused by an OLS estimation of both demand and

\footnotetext{
${ }^{14}$ A reviewer made a very good point: the significant portion of water demanded is not used by water buyers. Since this employs total amounts of water sold to customers as water demand, it includes both consumptive and diverted components of water demanded. But data on each component of water demanded is not available. For more details on human use of water, see Shaw (2005, pp. 11-14).

${ }^{15}$ To create a variable on the population density of service area (measured as people served per square mile), the following data sources were utilized: the U.S. Census' State and County QuickFacts, from http://quickfacts.census.gov/qfd/index.html; Wikipedia from http://en.wikipedia.org. In addition, the author searched Websites of individual water utilities.
} 
price equations ${ }^{16}$ and also to account for potential cross-equation error correlations (Zellner and Theil 1962; Kennedy 2001, pp. 166-167). ${ }^{17}$ The Stata statistical package is utilized for empirical analysis. This paper employs four stratified water prices. Thus, the equation of each water price is estimated along with the demand equation for water supply (for more details, see below).

Most data were obtained from the 2004 Water and Wastewater Rate Survey conducted by the American Water Works Association (AWWA)/Raftelis Financial Consulting. The unit of analysis is water utilities. Data are cross-sectional, representing 259 water utilities in 2004. Water utilities in Alaska and Hawaii are not included.

\section{VARIABLE DEFINITIONS AND DESCRIPTIVE STATISTICS}

\subsection{Variable Definitions and Expected Signs}

In the price equation for water supply in Equation (4), four dependent variables are employed for empirical analysis on variations in water prices across water utilities.

- Monthly water charges per Ccf (residential, $10 \mathrm{Ccf}$ )

- Monthly water charges per Ccf (residential, $30 \mathrm{Ccf}$ )

- Monthly water charges per Ccf (non-residential, $500 \mathrm{Ccf}$ )

- Monthly water charges per Ccf (non-residential, 10,000 Ccf)

Note that water utilities adopt different pricing mechanisms such as increasing or decreasing block rates, uniform rates, and flat fee rates. Thus, it is difficult to measure water price per Ccf across utilities, regardless of accounting for how many Ccfs of water are consumed and by whom (residential versus non-residential) (Shaw 2005, pp. 109121). To avoid this difficulty, four stratified cases of water prices are employed in measuring water price per Ccf. They also take into account different pricing rate structures across water utilities. For example, monthly water charges per Ccf (residential, 10 Ccf) means the dollar amounts per Ccf charged to a residential user who consumes 10 Ccf of water for one month, and monthly water charges per Ccf (non-residential, 500 Ccf) means the dollar amounts per Ccf charged to a non-residential user who consumes $500 \mathrm{Ccf}$ of water for one month. For empirical analysis, water prices are monthly water

\footnotetext{
${ }^{16}$ The simultaneous-equations model satisfies the order and rank conditions for identification. In addition, the results from the Hausman specification test generally confirm the endogeneity problem between total gallons of water sold and monthly water charges per Ccf.

${ }^{17}$ There are other regional factors that may affect water price and water demanded but are not accounted for in our estimated models. These unexplained regional factors are captured in error terms, $\mu_{i}$ and $v_{i}$, which are likely to be closely related to each other. In other words, it violates the zero covariance assumption among error terms. If the disturbances in the structural equations are correlated, the 3SLS procedure produces more efficient parameter estimates than the two-stage least squares (2SLS) procedure. If they are not correlated, 3SLS becomes identical to 2SLS (Melchelsen, Booker, and Person 2000; Kennedy 2001, pp. 166-167).
} 
TABLE 2

\section{Variable Definitions}

\begin{tabular}{|c|c|c|}
\hline Variable & Definition & $\begin{array}{l}\text { Expected } \\
\text { Sign }\end{array}$ \\
\hline $\ln ($ Water Sold $)$ & $\begin{array}{l}\text { Total } 100 \text { cubic feet (Ccf) of water sold (the natural } \\
\text { logarithm form) }\end{array}$ & + \\
\hline Govt. Ownership & $\begin{array}{l}1 \text { if a water utility is owned and operated by govt. } \\
\text { entity, } 0 \text { otherwise }\end{array}$ & $+/-$ \\
\hline City Ownership & $\begin{array}{l}1 \text { if a water utility is owned and operated by city govt., } \\
0 \text { otherwise }\end{array}$ & - \\
\hline County Ownership & $\begin{array}{l}1 \text { if a water utility is owned and operated by county } \\
\text { govt., } 0 \text { otherwise }\end{array}$ & $+/-$ \\
\hline District Ownership & $\begin{array}{l}1 \text { if a water utility is owned and operated by water } \\
\text { district govt., } 0 \text { otherwise }\end{array}$ & $+/-$ \\
\hline Bills Combined & $\begin{array}{l}1 \text { if the water bill is combined with other bill(s), } 0 \\
\text { otherwise }\end{array}$ & $+/-$ \\
\hline Increasing Block Rates & $\begin{array}{l}1 \text { if increasing block rates are used in a water utility, } 0 \\
\text { otherwise }\end{array}$ & + \\
\hline Seasonal Peak Rates & $\begin{array}{l}1 \text { if seasonal peak rates are charged in a water utility, } 0 \\
\text { otherwise }\end{array}$ & - \\
\hline $\begin{array}{l}\text { Provision of Other } \\
\quad \text { Infrastructure Services }\end{array}$ & $\begin{array}{l}1 \text { if a water utility provides other infrastructure } \\
\text { services, } 0 \text { otherwise }\end{array}$ & $+/-$ \\
\hline $\ln$ (Long-Term Debts) & Total long-term debts (the natural logarithm form) & + \\
\hline Water Rate Regulation & $\begin{array}{l}1 \text { if water retail rate is regulated by state public utility } \\
\text { commission, } 0 \text { otherwise }\end{array}$ & - \\
\hline LCV Index & $\begin{array}{l}\text { Proxy for state environmental regulations and } \\
\text { commitments to environmental conservation }\end{array}$ & + \\
\hline $\begin{array}{l}\text { Doctrine of Prior } \\
\quad \text { Appropriation (dummy) }\end{array}$ & $\begin{array}{l}1 \text { if the state where a water utility is located adopts the } \\
\text { DPA rights, } 0 \text { otherwise }\end{array}$ & + \\
\hline $\begin{array}{l}\text { Doctrine of Prior } \\
\quad \text { Appropriation (index) }\end{array}$ & $\begin{array}{l}2 \text { if the state where a water utility is located adopts the } \\
\text { DPA rights exclusively, } 1 \text { if it adopts both the DPA } \\
\text { rights and the riparian rights, and } 0 \text { if it has the } \\
\text { riparian rights exclusively. }\end{array}$ & + \\
\hline $\begin{array}{l}\ln (\text { Daily Water Treatment } \\
\text { Capacity) }\end{array}$ & $\begin{array}{l}\text { Natural log of daily water treatment capacity in a water } \\
\text { utility (Ccf per day) }\end{array}$ & - \\
\hline $\begin{array}{l}\ln (\text { Maximum Daily Water } \\
\text { Production) }\end{array}$ & $\begin{array}{l}\text { Natural log of maximum daily water production } \\
\text { capacity in a water utility (Ccf per day) }\end{array}$ & - \\
\hline Ground Water & $\begin{array}{l}\text { Share of groundwater withdrawals in total water } \\
\text { withdrawals }(\%)\end{array}$ & $+/-$ \\
\hline Surface Water & $\begin{array}{l}\text { Share of surface water withdrawals in total water } \\
\text { withdrawals }(\%)\end{array}$ & $+/-$ \\
\hline Water Loss & $\begin{array}{l}\text { Water loss during water production, treatment and } \\
\text { delivery }(\%)\end{array}$ & + \\
\hline
\end{tabular}


charges per Ccf. Therefore, each water utility has four cases of monthly water charges per Ccf. This approach takes into account both average price and marginal price.

Seven variables are used to represent institutional arrangements and characteristics of water utilities in the price equation for water supply. The first variable is DPA rights versus riparian rights. Water utilities under the DPA rights system are likely to have higher water prices than those under the riparian rights system because appropriative rights can be bought and sold under the DPA system and water rights prices are incorporated in water prices. As shown in Table 2, two measures are employed for empirical analysis: (a) 1 if the state where a water utility is located adopts the DPA rights, 0 otherwise (dummy), and (b) 2 if the state where a water utility is located adopts the DPA rights exclusively, 1 if it adopts both the DPA rights and the riparian rights, and 0 if it adopts the riparian rights exclusively.

The second variable, regarding higher water prices between private ownership ${ }^{18}$ and public ownership (i.e., city, county, or water district), is unknown a priori. As previously mentioned, however, under city ownership, prices are likely to be lower than in other types of ownership (including private ownership) because city governments have stronger incentives toward lower water prices than county or district governments or private companies.

Third, it is not known whether water prices are significantly lower when the water bill is combined with other bill(s) (such as refuse collection, stormwater, electricity, and wastewater collection and treatment). When the water bill is combined with other bills, water utilities may be able to charge water users higher water prices because it may be difficult for users to recognize it in one combined bill. In contrast, water utilities also may be able to transfer some water costs to other bills, which could lead to lower water prices. Fourth, employing increasing block rates for users will contribute to higher water prices than if other pricing rate structures are used (i.e., flat charges, uniform rates, or decreasing block rates). ${ }^{19}$ Fifth, when seasonal peak rates are charged, regular water charges may be lower because water utilities may be able to charge high seasonal peak rates for a period of time instead of higher regular charges.

Sixth, some water utilities provide other infrastructure services (such as wastewater collection and treatment, electric services, solid waste collection and disposal, and natural gas services) as well as water supply services. But it is not known whether this will lead to higher or lower water prices. From the perspective of economies of scope, the provision of other services may contribute to lower prices because water utilities can share personnel, machines, buildings, and equipment and may not need much additional investment to provide other services. In addition, if water utilities transfer some water costs to

\footnotetext{
${ }^{18}$ Private ownership includes water utilities owned by homeowners' associations/cooperatives as well as private water companies.

${ }^{19}$ Renwick, Green, and McCorkle (1998) observe that the marginal price of water is generally higher under increasing block pricing schedules than under uniform rates.
} 
other services (e.g., the price of electric services or the price of wastewater treatment), the provision of other services will also lead to lower water prices. However, if utilities transfer all or part of other services' costs to the cost of water supply, it will result in higher water prices. Seventh, water utilities will be more likely to charge higher prices to repay any debts they may have.

The price equation for water supply employs several variables to represent supply factors and characteristics. First, the greater daily water treatment capacity (Ccf per day) a water utility has, the lower its water prices are likely to be. Second, the greater maximum daily water production (Ccf per day) a water utility has, the lower its water prices are likely to be. Third, as previously mentioned, which source a water utility relies on most (groundwater, surface water, or water purchase) will lead to higher water prices, is unknown. However, one empirical study found that the unit water supply cost increases significantly when using surface or purchased water as opposed to groundwater (Shih et al. 2004). Fourth, the estimated percentage of water loss is employed to represent the overall inefficiency in the maintenance and operation of a water supply system, as larger water losses during water production, treatment, and delivery are likely to lead to higher water prices. ${ }^{20}$

The price equation for water supply employs two variables to account for government regulations. First, when water rates are regulated by state public utility commissions, water prices are likely to be lower. Employing the U.K. water industry data, Saal and Parker (2000) found that price regulation negatively influences water supply costs significantly. Second, the price equation employs an index to account for state environmental regulations and commitments. ${ }^{21}$ As shown in Table 3, Levinson (1999) constructed an

${ }^{20}$ A reviewer made a very good point: return flows from incomplete consumption may affect water prices. But we could not include this, mainly because of data unavailability.

${ }^{21}$ There are four other indices that represent state environmental regulations and commitments. The Conservation Foundation (CF) Index was constructed by Duerksen (1983) from 23 components, including environmental and land-use characteristics such as the League of Conservation Voters' assessment of voting records by each state's Congressional delegates, the existence of state environmental impact statement processes, and the existence of language specifically protecting the environment in state land-use statutes. The Fund for Renewable Energy and the Environment (FREE, 1987) constructed the FREE Index to measure the strength of state environmental programs. The components of the Index include state laws regarding air quality, hazardous waste, and groundwater pollution. The Green Index was constructed by Hall and Kerr (1991) to evaluate state environmental health from 256 measures of public policy and environmental quality. The Southern Studies (SS) Index was constructed by the Institute for Southern Studies (1994) from 20 environmental measures such as air quality, state spending on the environment, pollution and waste generation, and energy efficiency. Except for the Green Index and the SS Index, higher scores in the other two indices represent greater stringency of environmental regulations and stronger state environmental commitments. In other words, it is expected that the Green Index and the SS Index are negatively related with prices or costs of infrastructure services across local places and states, while the other two indices are positively related with them. But since these four indices are constructed using old data, they are not appropriate to be used for analyzing the effects of state environmental commitments and regulations on the price of water supply in this paper. 
index known as the LCV Index based on voting records on environmental bills compiled by the League of Conservation Voters. He averaged environmental voting records by each state's House and Senate delegations. States with high scores represent those with stringent environmental regulations and strong commitments to environmental conservation. Thus, high LCV Index scores imply high compliance costs and potentially higher water prices.

\section{TABLE 3}

\section{LCV Index}

\begin{tabular}{lclc}
\hline \multicolumn{1}{c}{ State } & LCV Index & \multicolumn{1}{c}{ State } & LCV Index \\
\hline Alabama & 24.4 & Nebraska & 40.9 \\
Arizona & 29.2 & Nevada & 38.1 \\
Arkansas & 43.7 & New Hampshire & 58.6 \\
California & 57.4 & New Jersey & 78.6 \\
Colorado & 48.0 & New Mexico & 30.0 \\
Connecticut & 74.0 & New York & 64.4 \\
Delaware & 67.8 & North Carolina & 34.2 \\
Florida & 50.3 & North Dakota & 43.8 \\
Georgia & 43.3 & Ohio & 61.5 \\
Idaho & 17.2 & Oklahoma & 27.5 \\
Illinois & 60.3 & Oregon & 53.9 \\
Indiana & 45.9 & Pennsylvania & 55.1 \\
Iowa & 54.5 & Rhode Island & 79.8 \\
Kansas & 35.5 & South Carolina & 41.4 \\
Kentucky & 32.3 & South Dakota & 51.1 \\
Louisiana & 25.7 & Tennessee & 43.2 \\
Maine & 77.1 & Texas & 28.3 \\
Maryland & 70.6 & Utah & 17.5 \\
Massachusetts & 86.6 & Vermont & 83.8 \\
Michigan & 67.9 & Virginia & 33.8 \\
Minnesota & 64.9 & Washington & 56.3 \\
Mississippi & 20.1 & West Virginia & 54.4 \\
Missouri & 42.6 & Wisconsin & 69.8 \\
Montana & 49.9 & Wyoming & 16.8 \\
\hline Source: Levinson $(1999)$. & & \\
\hline & & & \\
\hline & & & \\
\hline
\end{tabular}




\subsection{Descriptive Statistics}

Table 4 provides descriptive statistics on the variables employed in the price equation for water supply. Water utilities differ across regions in terms of water sold, water treatment capacity, water production capacity, population served, and water accounts and are generally larger in the Middle Atlantic and the Southwest regions than in the Midwest, New England, the West, and the South. Population density is generally higher among water utilities in New England and the Middle Atlantic regions than in the other regions.

Monthly water charges per Ccf decrease with changes in the type of water user (from residential to non-residential) and by level of water consumption (from $10 \mathrm{Ccf}$ to 10,000 Ccf). Charges also vary considerably across regions, with the Middle Atlantic and New England states higher than average. About 14 percent of water utilities charge seasonal peak rates, ranging from about 6 percent in the South to 25 percent in the West. The water bill is combined with other bill(s) in most water utilities except in the Middle Atlantic and New England regions. Increasing block rates as pricing rate structures are used for residential users more often than for non-residential users. Water utilities levy either voluntary or mandatory restrictions on water use in the Middle Atlantic and the South (about 70 percent and 50 percent, respectively) more often than in the other regions (about 22 percent to 33 percent).

One hundred one water utilities out of 259 total sample utilities (about 39 percent) are located in states that adopt DPA rights. Among them, 75 utilities are located in the states that adopt both the DPA rights and riparian rights systems, and 26 utilities are located in the states that adopt DPA rights exclusively. About 96 percent of water utilities are owned and operated by government entities (city, county, or water district), ranging from about 83 percent in the Middle Atlantic to 100 percent in the Midwest and the Southwest. But in the Middle Atlantic region, water districts provide more water supply services (about 42 percent), while cities provide more water supply services in the Midwest and the Southwest (about 92 percent and 96 percent, respectively).

Water utilities in New England rely more heavily on surface water (about 82 percent) as their raw water source than groundwater (about 5 percent). Water utilities in other regions use groundwater (about 31 percent in the Middle Atlantic and 43 percent in the South) and surface water (about 36 percent in the West and 61 percent in the Middle Atlantic). Water utilities also purchase water from other utilities (about 5 percent in both the Midwest and the South and 28 percent in the West).

Three regions (Middle Atlantic, Midwest, and New England) have more characteristics in common compared with the other three regions (South, Southwest, and West). First, water utilities in these three regions provide other infrastructure services to both residential and non-residential users less frequently than those in the latter regions. About 45-57 percent of water utilities do so in the former regions, compared with about 76-94 percent in the latter. Second, water rates are regulated by state public utility commissions in the former (about 19-33 percent) more often than in the latter (about 3-8 percent). 
TABLE 4

\begin{tabular}{|c|c|c|c|c|c|c|c|}
\hline & $\frac{\text { All Regions }}{\begin{array}{c}\text { Mean } \\
\text { (std. dev.) }\end{array}}$ & 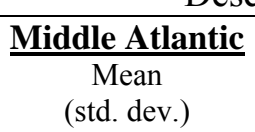 & $\begin{array}{l}\frac{\text { Midwest }}{\text { Mean }} \\
\text { (std. dev.) }\end{array}$ & $\frac{\text { New England }}{\begin{array}{c}\text { Mean } \\
\text { (std. dev.) }\end{array}}$ & $\begin{array}{l}\frac{\text { South }}{\text { Mean }} \\
\text { (std. dev.) }\end{array}$ & $\begin{array}{l}\text { Southwest } \\
\begin{array}{c}\text { Mean } \\
\text { (std. dev.) }\end{array}\end{array}$ & $\begin{array}{c}\frac{\text { West }}{\text { Mean }} \\
\text { (std. dev.) }\end{array}$ \\
\hline Water Sold (million Ccf) & $\begin{array}{c}24.90 \\
(50.40)\end{array}$ & $\begin{array}{c}39.60 \\
(112.00)\end{array}$ & $\begin{array}{c}15.90 \\
(17.10)\end{array}$ & $\begin{array}{c}20.70 \\
(28.60)\end{array}$ & $\begin{array}{c}19.40 \\
(36.90)\end{array}$ & $\begin{array}{c}36.20 \\
(43.70)\end{array}$ & $\begin{array}{c}27.30 \\
(42.10)\end{array}$ \\
\hline \multicolumn{8}{|l|}{ Monthly charges per Ccf } \\
\hline Residential, $10 \mathrm{Ccf}$ & $\begin{array}{c}1.97 \\
(0.71)\end{array}$ & $\begin{array}{c}2.53 \\
(0.79)\end{array}$ & $\begin{array}{c}1.77 \\
(0.63)\end{array}$ & $\begin{array}{c}2.20 \\
(0.82)\end{array}$ & $\begin{array}{c}1.90 \\
(0.72)\end{array}$ & $\begin{array}{c}1.85 \\
(0.53)\end{array}$ & $\begin{array}{c}1.96 \\
(0.63)\end{array}$ \\
\hline Residential, $30 \mathrm{Ccf}$ & $\begin{array}{c}1.77 \\
(0.68)\end{array}$ & $\begin{array}{c}2.35 \\
(0.72)\end{array}$ & $\begin{array}{c}1.58 \\
(0.57)\end{array}$ & $\begin{array}{l}1.97 \\
(0.76)\end{array}$ & $\begin{array}{l}1.76 \\
(0.72)\end{array}$ & $\begin{array}{l}1.80 \\
(0.53)\end{array}$ & $\begin{array}{l}1.60 \\
(0.57)\end{array}$ \\
\hline Non-Residential, $500 \mathrm{Ccf}$ & $\begin{array}{c}1.51 \\
(0.62)\end{array}$ & $\begin{array}{l}1.85 \\
(0.71)\end{array}$ & $\begin{array}{c}1.36 \\
(0.51)\end{array}$ & $\begin{array}{l}1.61 \\
(0.57)\end{array}$ & $\begin{array}{c}1.51 \\
(0.69)\end{array}$ & $\begin{array}{c}1.57 \\
(0.46)\end{array}$ & $\begin{array}{c}1.38 \\
(0.57)\end{array}$ \\
\hline Non-Residential, 10,000 Ccf & $\begin{array}{l}1.36 \\
(0.64)\end{array}$ & $\begin{array}{l}1.73 \\
(0.78)\end{array}$ & $\begin{array}{l}1.13 \\
(0.50)\end{array}$ & $\begin{array}{l}1.40 \\
(0.68)\end{array}$ & $\begin{array}{c}1.31 \\
(0.69)\end{array}$ & $\begin{array}{c}1.52 \\
(0.52)\end{array}$ & $\begin{array}{l}1.33 \\
(0.55)\end{array}$ \\
\hline \multicolumn{8}{|l|}{ Ownership } \\
\hline Government & $\begin{array}{c}0.96 \\
(0.20)\end{array}$ & $\begin{array}{c}0.83 \\
(0.38)\end{array}$ & $\begin{array}{c}1.00 \\
(0.01)\end{array}$ & $\begin{array}{c}0.93 \\
(0.26)\end{array}$ & $\begin{array}{c}0.99 \\
(0.11)\end{array}$ & $\begin{array}{c}1.00 \\
(0.01)\end{array}$ & $\begin{array}{c}0.93 \\
(0.25)\end{array}$ \\
\hline City & $\begin{array}{c}0.68 \\
(0.46)\end{array}$ & $\begin{array}{c}0.30 \\
(0.46)\end{array}$ & $\begin{array}{c}0.92 \\
(0.25)\end{array}$ & $\begin{array}{c}0.60 \\
(0.51)\end{array}$ & $\begin{array}{c}0.59 \\
(0.49)\end{array}$ & $\begin{array}{c}0.96 \\
(0.19)\end{array}$ & $\begin{array}{c}0.66 \\
(0.48)\end{array}$ \\
\hline County & $\begin{array}{c}0.06 \\
(0.23)\end{array}$ & $\begin{array}{c}0.07 \\
(0.26)\end{array}$ & $\begin{array}{c}0.00 \\
(0.01)\end{array}$ & $\begin{array}{c}0.00 \\
(0.00)\end{array}$ & $\begin{array}{c}0.16 \\
(0.36)\end{array}$ & $\begin{array}{c}0.00 \\
(0.01)\end{array}$ & $\begin{array}{c}0.02 \\
(0.13)\end{array}$ \\
\hline District & $\begin{array}{c}0.20 \\
(0.40)\end{array}$ & $\begin{array}{c}0.42 \\
(0.50)\end{array}$ & $\begin{array}{c}0.05 \\
(0.21)\end{array}$ & $\begin{array}{c}0.33 \\
(0.49)\end{array}$ & $\begin{array}{c}0.21 \\
(0.40)\end{array}$ & $\begin{array}{c}0.04 \\
(0.18)\end{array}$ & $\begin{array}{c}0.26 \\
(0.44)\end{array}$ \\
\hline \multicolumn{8}{|l|}{ Seasonal Peak Rates } \\
\hline Residential, 10 C cf & $\begin{array}{c}0.14 \\
(0.35)\end{array}$ & $\begin{array}{c}0.10 \\
(0.31)\end{array}$ & $\begin{array}{c}0.13 \\
(0.34)\end{array}$ & $\begin{array}{c}0.20 \\
(0.41)\end{array}$ & $\begin{array}{c}0.06 \\
(0.25)\end{array}$ & $\begin{array}{c}0.23 \\
(0.43)\end{array}$ & $\begin{array}{c}0.20 \\
(0.41)\end{array}$ \\
\hline Residential, 30 Ccf & $\begin{array}{c}0.14 \\
(0.34)\end{array}$ & $\begin{array}{c}0.10 \\
(0.31)\end{array}$ & $\begin{array}{c}0.11 \\
(0.31)\end{array}$ & $\begin{array}{c}0.20 \\
(0.41)\end{array}$ & $\begin{array}{c}0.06 \\
(0.25)\end{array}$ & $\begin{array}{c}0.23 \\
(0.43)\end{array}$ & $\begin{array}{c}0.20 \\
(0.41)\end{array}$ \\
\hline Non-Residential, $500 \mathrm{Ccf}$ & $\begin{array}{c}0.14 \\
(0.35)\end{array}$ & $\begin{array}{c}0.10 \\
(0.31)\end{array}$ & $\begin{array}{c}0.11 \\
(0.31)\end{array}$ & $\begin{array}{c}0.13 \\
(0.35)\end{array}$ & $\begin{array}{c}0.06 \\
(0.25)\end{array}$ & $\begin{array}{c}0.23 \\
(0.43)\end{array}$ & $\begin{array}{r}0.25 \\
(0.44) \\
\end{array}$ \\
\hline
\end{tabular}




\begin{tabular}{|c|c|c|c|c|c|c|c|}
\hline & $\begin{array}{c}\text { All Regions } \\
\text { Mean } \\
\text { (std. dev.) }\end{array}$ & $\begin{array}{c}\text { Middle Atlantic } \\
\text { Mean } \\
\text { (std. dev.) }\end{array}$ & $\begin{array}{c}\text { Midwest } \\
\text { Mean } \\
\text { (std. dev.) }\end{array}$ & $\begin{array}{c}\frac{\text { New England }}{\text { Mean }} \\
\text { (std. dev.) }\end{array}$ & $\begin{array}{c}\text { South } \\
\text { Mean } \\
\text { (std. dev.) }\end{array}$ & $\begin{array}{c}\frac{\text { Southwest }}{\text { Mean }} \\
\text { (std. dev.) }\end{array}$ & $\begin{array}{c}\text { West } \\
\text { Mean } \\
\text { (std. dev.) }\end{array}$ \\
\hline \multicolumn{8}{|l|}{ Seasonal Peak Rates (Continued) } \\
\hline Non-Residential, $10,000 \mathrm{Ccf}$ & $\begin{array}{c}0.14 \\
(0.35)\end{array}$ & $\begin{array}{c}0.10 \\
(0.31)\end{array}$ & $\begin{array}{c}0.11 \\
(0.31)\end{array}$ & $\begin{array}{c}0.13 \\
(0.35)\end{array}$ & $\begin{array}{c}0.06 \\
(0.25)\end{array}$ & $\begin{array}{c}0.23 \\
(0.43)\end{array}$ & $\begin{array}{c}0.25 \\
(0.44)\end{array}$ \\
\hline Bills Combined & $\begin{array}{c}0.81 \\
(0.39)\end{array}$ & $\begin{array}{c}0.45 \\
(0.51)\end{array}$ & $\begin{array}{c}0.89 \\
(0.31)\end{array}$ & $\begin{array}{c}0.53 \\
(0.52)\end{array}$ & $\begin{array}{c}0.94 \\
(0.25)\end{array}$ & $\begin{array}{c}0.97 \\
(0.18)\end{array}$ & $\begin{array}{c}0.76 \\
(0.43)\end{array}$ \\
\hline \multicolumn{8}{|l|}{ Increasing Block Rates } \\
\hline Residential & $\begin{array}{c}0.36 \\
(0.48)\end{array}$ & $\begin{array}{c}0.17 \\
(0.38)\end{array}$ & $\begin{array}{c}0.21 \\
(0.41)\end{array}$ & $\begin{array}{c}0.20 \\
(0.41)\end{array}$ & $\begin{array}{c}0.37 \\
(0.49)\end{array}$ & $\begin{array}{c}0.61 \\
(0.50)\end{array}$ & $\begin{array}{c}0.44 \\
(0.50)\end{array}$ \\
\hline Non-Residential & $\begin{array}{c}0.23 \\
(0.42)\end{array}$ & $\begin{array}{c}0.14 \\
(0.35)\end{array}$ & $\begin{array}{c}0.21 \\
(0.41)\end{array}$ & $\begin{array}{c}0.20 \\
(0.41)\end{array}$ & $\begin{array}{c}0.26 \\
(0.44)\end{array}$ & $\begin{array}{c}0.35 \\
(0.49)\end{array}$ & $\begin{array}{c}0.20 \\
(0.41)\end{array}$ \\
\hline $\begin{array}{l}\text { Provision of Other Infrastructure } \\
\text { Services }\end{array}$ & $\begin{array}{c}0.71 \\
(0.45)\end{array}$ & $\begin{array}{c}0.45 \\
(0.51)\end{array}$ & $\begin{array}{c}0.57 \\
(0.50)\end{array}$ & $\begin{array}{c}0.53 \\
(0.52)\end{array}$ & $\begin{array}{c}0.81 \\
(0.40)\end{array}$ & $\begin{array}{c}0.94 \\
(0.25)\end{array}$ & $\begin{array}{c}0.76 \\
(0.43)\end{array}$ \\
\hline Long-Term Debts (Million\$) & $\begin{array}{l}116 \\
(344)\end{array}$ & $\begin{array}{c}204 \\
(770)\end{array}$ & $\begin{array}{c}72 \\
(195)\end{array}$ & $\begin{array}{l}116 \\
(284)\end{array}$ & $\begin{array}{c}69 \\
(124)\end{array}$ & $\begin{array}{c}232 \\
(421)\end{array}$ & $\begin{array}{l}110 \\
(249)\end{array}$ \\
\hline Water Rate Regulation & $\begin{array}{c}0.12 \\
(0.31)\end{array}$ & $\begin{array}{c}0.24 \\
(0.44)\end{array}$ & $\begin{array}{c}0.19 \\
(0.40)\end{array}$ & $\begin{array}{c}0.33 \\
(0.49)\end{array}$ & $\begin{array}{c}0.03 \\
(0.16)\end{array}$ & $\begin{array}{c}0.06 \\
(0.18)\end{array}$ & $\begin{array}{c}0.08 \\
(0.25)\end{array}$ \\
\hline LCV Index & $\begin{array}{c}48.31 \\
(15.69)\end{array}$ & $\begin{array}{l}61.69 \\
(6.76)\end{array}$ & $\begin{array}{c}56.71 \\
(11.30)\end{array}$ & $\begin{array}{l}76.57 \\
(8.85)\end{array}$ & $\begin{array}{l}39.75 \\
(8.77)\end{array}$ & $\begin{array}{l}28.45 \\
(0.59)\end{array}$ & $\begin{array}{c}49.61 \\
(13.63)\end{array}$ \\
\hline \multicolumn{8}{|l|}{ Doctrine of Prior Appropriation } \\
\hline Dummy & $\begin{array}{c}0.39 \\
(0.49)\end{array}$ & $\begin{array}{c}0.00 \\
(0.00)\end{array}$ & $\begin{array}{c}0.23 \\
(0.43)\end{array}$ & $\begin{array}{c}0.00 \\
(0.00)\end{array}$ & $\begin{array}{c}0.00 \\
(0.00)\end{array}$ & $\begin{array}{c}1.00 \\
(0.00)\end{array}$ & $\begin{array}{c}1.00 \\
(0.00)\end{array}$ \\
\hline Index & $\begin{array}{c}0.49 \\
(0.67)\end{array}$ & $\begin{array}{c}0.00 \\
(0.00)\end{array}$ & $\begin{array}{c}0.23 \\
(0.43)\end{array}$ & $\begin{array}{c}0.00 \\
(0.00)\end{array}$ & $\begin{array}{c}0.00 \\
(0.00)\end{array}$ & $\begin{array}{c}1.26 \\
(0.44)\end{array}$ & $\begin{array}{c}1.31 \\
(0.46)\end{array}$ \\
\hline Ground Water $(\%)$ & $\begin{array}{c}35.35 \\
(41.97)\end{array}$ & $\begin{array}{c}31.00 \\
(39.29)\end{array}$ & $\begin{array}{c}39.03 \\
(45.13)\end{array}$ & $\begin{array}{c}4.82 \\
(12.54)\end{array}$ & $\begin{array}{c}42.57 \\
(45.76)\end{array}$ & $\begin{array}{c}29.79 \\
(39.88)\end{array}$ & $\begin{array}{c}35.70 \\
(38.53)\end{array}$ \\
\hline Surface Water (5) & $\begin{array}{c}52.35 \\
(44.96)\end{array}$ & $\begin{array}{c}61.04 \\
(41.97)\end{array}$ & $\begin{array}{c}56.33 \\
(46.39)\end{array}$ & $\begin{array}{c}81.51 \\
(35.40)\end{array}$ & $\begin{array}{c}52.37 \\
(45.60)\end{array}$ & $\begin{array}{c}55.30 \\
(45.15)\end{array}$ & $\begin{array}{c}35.91 \\
(42.05)\end{array}$ \\
\hline Water Purchase $(\%)$ & $\begin{array}{c}12.30 \\
(28.83)\end{array}$ & $\begin{array}{c}7.95 \\
(21.00)\end{array}$ & $\begin{array}{c}4.64 \\
(20.43)\end{array}$ & $\begin{array}{c}13.67 \\
(35.07)\end{array}$ & $\begin{array}{c}5.06 \\
(17.08)\end{array}$ & $\begin{array}{c}14.92 \\
(34.52)\end{array}$ & $\begin{array}{c}28.40 \\
(38.19)\end{array}$ \\
\hline Water Loss $(\%)$ & $\begin{array}{l}10.51 \\
(9.06)\end{array}$ & $\begin{array}{c}16.76 \\
(9.79)\end{array}$ & $\begin{array}{l}11.02 \\
(7.07)\end{array}$ & $\begin{array}{l}12.07 \\
(7.38)\end{array}$ & $\begin{array}{c}10.70 \\
(11.81)\end{array}$ & $\begin{array}{c}9.16 \\
(6.37)\end{array}$ & $\begin{array}{c}7.10 \\
(5.17)\end{array}$ \\
\hline
\end{tabular}




\begin{tabular}{|c|c|c|c|c|c|c|c|}
\hline & $\begin{array}{c}\text { All Regions } \\
\text { Mean } \\
\text { (std. dev.) }\end{array}$ & $\begin{array}{c}\text { Middle Atlantic } \\
\text { Mean } \\
\text { (std. dev.) }\end{array}$ & $\begin{array}{c}\text { Midwest } \\
\text { Mean } \\
\text { (std. dev.) }\end{array}$ & 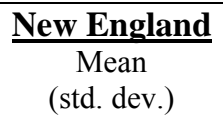 & $\begin{array}{c}\text { South } \\
\begin{array}{c}\text { Mean } \\
\text { (std. dev.) }\end{array}\end{array}$ & $\begin{array}{c}\text { Southwest } \\
\text { Mean } \\
\text { (std. dev.) }\end{array}$ & $\begin{array}{c}\text { West } \\
\text { Mean } \\
\text { (std. dev.) }\end{array}$ \\
\hline $\begin{array}{l}\text { Daily Water Treatment Capacity } \\
\text { (Ccf per day) }\end{array}$ & $\begin{array}{c}144,770 \\
(232,921)\end{array}$ & $\begin{array}{c}193,998 \\
(445,106)\end{array}$ & $\begin{array}{c}117,193 \\
(140,574)\end{array}$ & $\begin{array}{c}113,162 \\
(134,416)\end{array}$ & $\begin{array}{c}94,489 \\
(97,243)\end{array}$ & $\begin{array}{c}269,864 \\
(355,917)\end{array}$ & $\begin{array}{c}151,322 \\
(183,522)\end{array}$ \\
\hline $\begin{array}{l}\text { Maximum Daily Water } \\
\text { Production (Ccf per day) }\end{array}$ & $\begin{array}{c}114,549 \\
(209,903)\end{array}$ & $\begin{array}{c}161,110 \\
(418,954)\end{array}$ & $\begin{array}{c}122,217 \\
(268,445)\end{array}$ & $\begin{array}{c}95,332 \\
(107,444)\end{array}$ & $\begin{array}{c}69,772 \\
(75,977)\end{array}$ & $\begin{array}{c}174,019 \\
(196,270)\end{array}$ & $\begin{array}{c}118,391 \\
(133,778)\end{array}$ \\
\hline Water Accounts & $\begin{array}{c}79,094 \\
(107,652)\end{array}$ & $\begin{array}{c}112,338 \\
(191,297)\end{array}$ & $\begin{array}{c}72,547 \\
(99,089)\end{array}$ & $\begin{array}{c}46,694 \\
(49,674)\end{array}$ & $\begin{array}{c}72,743 \\
(69,707)\end{array}$ & $\begin{array}{c}110,012 \\
(111,129)\end{array}$ & $\begin{array}{r}68,359 \\
(105,462)\end{array}$ \\
\hline Served Population & $\begin{array}{c}377,260 \\
(781,769)\end{array}$ & $\begin{array}{c}611,656 \\
(1,678,569)\end{array}$ & $\begin{array}{c}356,147 \\
(798,614)\end{array}$ & $\begin{array}{c}364,358 \\
(551,781)\end{array}$ & $\begin{array}{l}261,002 \\
(319,385)\end{array}$ & $\begin{array}{c}478,311 \\
(558,937)\end{array}$ & $\begin{array}{c}382,749 \\
(656,146)\end{array}$ \\
\hline People per Square Mile & $\begin{array}{c}2,888 \\
(2,889)\end{array}$ & $\begin{array}{c}3,905 \\
(5,172)\end{array}$ & $\begin{array}{c}3,140 \\
(2,127)\end{array}$ & $\begin{array}{c}4,782 \\
(5,017)\end{array}$ & $\begin{array}{c}1,549 \\
(1,070)\end{array}$ & $\begin{array}{r}2,275 \\
(878)\end{array}$ & $\begin{array}{c}3,796 \\
(2,769)\end{array}$ \\
\hline Water Use Restrictions & $\begin{array}{c}0.38 \\
(0.48) \\
\end{array}$ & $\begin{array}{c}0.70 \\
(0.46) \\
\end{array}$ & $\begin{array}{c}0.22 \\
(0.40) \\
\end{array}$ & $\begin{array}{c}0.29 \\
(0.45) \\
\end{array}$ & $\begin{array}{c}0.50 \\
(0.49) \\
\end{array}$ & $\begin{array}{c}0.33 \\
(0.47)\end{array}$ & $\begin{array}{c}0.24 \\
(0.43)\end{array}$ \\
\hline $\mathrm{N}$ & 259 & 29 & 47 & 15 & 78 & 31 & 59 \\
\hline
\end{tabular}


Third, water utilities generally adopt increasing block rates for both residential and nonresidential use in the former regions less often than in the latter regions. Fourth, the LCV indices are higher in the former than in the latter, implying that state governments in the former regions impose stricter environmental regulations and stronger environmental commitments than their counterparts in the latter regions. Fifth, water utilities in the former regions lose more water during the production, treatment, and delivery of water than those in the latter regions. For example, the West has the highest efficiency rate (with water losses of only about 7 percent), while the least efficient region is the Middle Atlantic (with water losses of about 17 percent).

\section{EMPIRICAL RESULTS}

As this paper focuses on geographical differences in water prices across water utilities, it presents only the 3 SLS results of the price equation for water supply. ${ }^{22}$ See Appendix Tables 1-4 for OLS results of the price equation for water supply.

\subsection{Monthly Water Charges per Ccf (Residential, 10 Ccf)}

Table 5 shows the 3SLS results for monthly water charges per Ccf (residential, 10 Ccf). All coefficients exhibit expected signs. $R^{2}$ ranges from about 0.16 to 0.22 across the four estimated models; ${ }^{23}$ and the $\chi^{2}$ values are very large, implying the overall significance of the estimated models. Total amounts of water sold, representing the quantity of water demanded, are positive and significant at the 1 percent level in the 3SLS estimations of all four models. But the coefficients are not so large. Along with a 1 percent increase in water demanded, monthly charges per Ccf (residential, $10 \mathrm{Ccf}$ ) also increased by about 0.15 percent to 0.19 percent.

Some institutional variables on water utilities significantly influence water prices. Water rights are a significant factor in influencing water prices. As shown in Models 1 and 2 of Table 5, under either the exclusive DPA rights system or the mixed system of the DPA and riparian rights, water prices are significantly higher than under the exclusive riparian rights system.

Water prices are not significantly different under government ownership than under private ownership, even when three different types of government ownership are taken

\footnotetext{
${ }^{22}$ This paper does not present empirical results on the demand equations for water supply. They are available upon request. The author estimated the equations and found that all water price variables are significant and negative at the significance level of 0.01 . This is generally consistent with empirical findings in previous literature (See, e.g., Renwick, Green, and McCorkle 1998; Barkatullah 2002). The paper also does not present first-stage estimation results on the price and demand equations for water supply. They also are available upon request.

${ }^{23}$ In $3 \mathrm{SLS}$, some regressors are used as instruments in model estimation. But in calculating $R^{2}$, the actual values are used, not the instruments. Thus, one should be careful in interpreting $R^{2}$ in the 3SLS. Some negative $R^{2}$ values are possible in 3SLS (StataCorp 2005, p. 22).
} 
TABLE 5

District Ownership

Water Rate Regulation

Seasonal Peak Rates

Provision of Other Infrastructure Services

In (Long-Term Debts)

Model 1

Estimate

Dependent Variable:

In (Monthly Chargers per Ccf)

$\begin{array}{llcc}\text { (Std. Error) } & \text { (Std. Error) } & \text { (Std. Error) } & \text { (Std. Error) }\end{array}$

$\ln ($ Water Sold)

$(0.568)$

0.4533

0.3575

Increasing Block Rates (Residential)

Bills Combined

$(0.070)$

0.1606

(0.622)

$(0.614)$

0.0009

$(0.070)$

0.1854

0.1916

(0.045)

0.0074

$(0.073)$

$-0.1857$

(0.044)

(0.044)

0.0269
$(0.044)$

Government Ownership

$-0.2076$

$(0.064)^{* * *}$

$-0.1914$

$-0.1818$

$-0.1945$

$(0.065)^{* * *}$

City Ownership

$(0.140)$

$-0.1219$

(0.143)

$-0.1313$

(0.107)

(0.109)

$-0.0906$

$-0.1068$

$(0.129)$

(0.130)

$-0.0666$

$-0.0698$

(0.106)

$(0.108)$

0.0054

0.0405

$-0.0138$

0.0170

$\quad(0.075)$

$-0.0212$

$(0.085)$

$(0.076)$

$-0.0182$

(0.056)

$-0.0139$

$-0.0177$

0.0787

0.0745

0.077

(0.057)

(0.049)

(0.048)

0.074

$0.0092 \quad 0.008$

(0.050)

(0.049)

$(0.003)^{* *}$

$(0.003)^{*}$

0.0085

ln (Daily Water Treatment Capacity)

$(0.053)^{* *}$

$-0.1333$

$(0.003)^{* * *}$

$(0.003)^{* * *}$

In (Maximum Daily Water Production)

$-0.1129$

$(0.052)^{* * *}$

$(0.005)^{* * *}$

$(0.054)^{* * *}$

$(0.046)^{* * *}$

$(0.045)^{* *}$

$(0.047)^{* * *}$

$(0.046)^{* * *}$ 


\begin{tabular}{|c|c|c|c|c|}
\hline $\begin{array}{l}\text { Dependent Variable: } \\
\text { In (Monthly Chargers per Ccf) }\end{array}$ & $\begin{array}{l}\frac{\text { Model 1 }}{\text { Estimate }} \\
\text { (Std. Error) }\end{array}$ & $\begin{array}{l}\frac{\text { Model 2 }}{\text { Estimate }} \\
\text { (Std. Error) }\end{array}$ & $\begin{array}{l}\frac{\text { Model 3 }}{\text { Estimate }} \\
\text { (Std. Error) }\end{array}$ & $\begin{array}{l}\frac{\text { Model 4 }}{\text { Estimate }} \\
\text { (Std. Error) }\end{array}$ \\
\hline Ground Water & $\begin{array}{l}-0.0018 \\
(0.001)^{* *}\end{array}$ & $\begin{array}{l}-0.0015 \\
(0.001)^{*}\end{array}$ & $\begin{array}{l}-0.0017 \\
(0.001)^{*}\end{array}$ & $\begin{array}{l}-0.0015 \\
(0.001)^{*}\end{array}$ \\
\hline Surface Water & $\begin{array}{l}-0.0004 \\
(0.001)\end{array}$ & $\begin{array}{l}-0.0003 \\
(0.001)\end{array}$ & $\begin{array}{l}-0.0003 \\
(0.001)\end{array}$ & $\begin{array}{l}-0.0003 \\
(0.001)\end{array}$ \\
\hline Water Loss & $\begin{array}{l}0.0074 \\
(0.002)^{* * *}\end{array}$ & $\begin{array}{l}0.0075 \\
(0.002)^{* * *}\end{array}$ & $\begin{array}{l}0.0071 \\
(0.002)^{* * *}\end{array}$ & $\begin{array}{l}0.0073 \\
(0.002)^{* * *}\end{array}$ \\
\hline LCV Index & $\begin{array}{c}0.0036 \\
(0.002)\end{array}$ & $\begin{array}{r}0.0031 \\
(0.002)\end{array}$ & $\begin{array}{c}0.0030 \\
(0.003)\end{array}$ & $\begin{array}{c}0.0026 \\
(0.003)\end{array}$ \\
\hline Doctrine of Prior Appropriation (Dummy) & $\begin{array}{l}0.3681 \\
(0.126)^{* * *}\end{array}$ & $\begin{array}{l}0.3494 \\
(0.127)^{* * *}\end{array}$ & & \\
\hline Doctrine of Prior Appropriation (Index) & & & $\begin{array}{l}0.1263 \\
(0.082)\end{array}$ & $\begin{array}{c}0.1219 \\
(0.083)\end{array}$ \\
\hline Middle Atlantic & $\begin{array}{c}0.3825 \\
(0.145)\end{array}$ & $\begin{array}{c}0.3603 \\
(0.149)^{* *}\end{array}$ & $\begin{array}{c}0.2086 \\
(0.130)\end{array}$ & $\begin{array}{c}0.1922 \\
(0.133)\end{array}$ \\
\hline Midwest & $\begin{array}{l}0.1373 \\
(0.118)\end{array}$ & $\begin{array}{r}0.1283 \\
(0.120)\end{array}$ & $\begin{array}{l}0.0225 \\
(0.111)\end{array}$ & $\begin{array}{c}0.0193 \\
(0.114)\end{array}$ \\
\hline New England & $\begin{array}{c}0.1858 \\
(0.166)\end{array}$ & $\begin{array}{c}0.1766 \\
(0.167)\end{array}$ & $\begin{array}{c}0.0230 \\
(0.157)\end{array}$ & $\begin{array}{c}0.0205 \\
(0.158)\end{array}$ \\
\hline South & $\begin{array}{l}0.3013 \\
(0.134)^{* *}\end{array}$ & $\begin{array}{c}0.2684 \\
(0.138)^{* *}\end{array}$ & $\begin{array}{c}0.1039 \\
(0.115)\end{array}$ & $\begin{array}{c}0.0820 \\
(0.119)\end{array}$ \\
\hline West & $\begin{array}{l}-0.0566 \\
(0.090)\end{array}$ & $\begin{array}{l}-0.0535 \\
(0.090)\end{array}$ & $\begin{array}{l}-0.0446 \\
(0.096) \\
\end{array}$ & $\begin{array}{l}-0.0455 \\
(0.096) \\
\end{array}$ \\
\hline $\mathrm{N}$ & 259 & 259 & 259 & 259 \\
\hline$\chi^{2}$ value & 113.35 & 112.19 & 100.45 & 100.36 \\
\hline Prob $>\chi^{2}$ & 0.000 & 0.000 & 0.000 & 0.000 \\
\hline$R^{2} \quad n$ & 0.2203 & 0.2061 & 0.1735 & 0.1647 \\
\hline
\end{tabular}


into account. ${ }^{24}$ This finding is consistent across the models and also with previous studies (see e.g., Bruggink 1982; Feigenbaum and Teeples 1983; Teeples and Glyer 1987; Shih et al. 2004).

When the water bill is combined with other bills, water prices are significantly lower, implying that water utilities transfer some water supply costs to other bills to lower water prices. When utilities have long-term debts, they often charge higher prices to water users, but the coefficients are not large.

Supply factors and characteristics also contribute to variations in water prices across utilities. Large daily water production and daily water treatment capacities significantly decrease water prices. The elasticity of water price with respect to daily water production capacity ranges from about -0.11 to -0.12 across the models, while the elasticity of water price with respect to daily water treatment capacity ranges from about -0.12 to -0.15 .

As water utilities lose more water during production, treatment, and delivery, water prices increase. Water utilities that rely on groundwater as their source pay lower costs than those that purchase water from other sources or use surface water as their source. ${ }^{25}$ There might be two reasons for this. First, since groundwater is generally cleaner than surface water, a reduced need for water treatment results in lower prices. Second, surface water storage requires large infrastructure expenditures, including dams (Hewitt 2000).

Neither water rate regulations nor the LCV Index for state environmental regulations and commitments have significant effects on water prices. Water prices are higher in the Middle Atlantic and South than in the Southwest.

\subsection{Monthly Water Charges per Ccf (Residential, 30 Ccf)}

Table 6 shows the 3SLS results for monthly water charges per Ccf (residential, 30 Ccf). All coefficients exhibit expected signs. $R^{2}$ ranges from about 0.19 to 0.22 across the four estimated models; and the $\chi^{2}$ values are very large, implying the overall significance of the estimated models. Total amounts of water sold are significant in the four models, and coefficients range from about 0.25 to 0.28 , implying that a 1 percent increase in water sold results in an increase in water monthly charges per $\mathrm{Ccf}$ (residential, $30 \mathrm{Ccf}$ ) by about 0.25 percent to 0.28 percent.

Some institutional variables are important in explaining water supply price differences across water utilities. Under either the exclusive DPA rights system or the mixed DPA and riparian rights systems, water prices are significantly higher than under the

\footnotetext{
${ }^{24}$ On the basis of joint $\chi^{2}$ test results $\left[\chi^{2}(3)=1.80\right]$ in Model 2 and $\left[\chi^{2}(3)=2.08\right]$ in Model 4, there are no significant differences in water prices among these types of government ownership.

${ }^{25}$ On the basis of joint $\chi^{2}$ test results $\left[\chi^{2}(2)=7.66\right]$ in Model $1,\left[\chi^{2}(2)=6.00\right]$ in Model 2, $\left[\chi^{2}(2)=7.63\right]$ in Model 3, and $\left[\chi^{2}(2)=6.09\right]$ in Model 4, in use of groundwater, water prices are significantly lower than in use of surface water.
} 
system of exclusive riparian rights, as shown in Models 1 and 2 of Table 6. Under the system of the exclusive DPA rights, water prices are significantly higher than under either the mixed system of the DPA and riparian rights or the system of exclusive riparian rights. In addition, water prices under the mixed system are significantly higher than those under the exclusive riparian rights. Under increasing block rates, water prices are higher. When the water bill is combined with other bills, it is much lower. Water prices under government ownership are not much different than those under private ownership across the four models. ${ }^{26}$

Long-term debts positively affect water prices, but their coefficients are small. The provision of other infrastructure services by water utilities contributes to higher water prices, implying that utilities transfer some costs of other services (e.g., electric, natural gas, and wastewater treatment services) to water prices. But caution should be taken when interpreting this finding as the existence of diseconomies of scope because the dependent variable in this paper is water price, not water supply cost (i.e., the cost of operation and maintenance in the water supply system). In other words, in spite of high water prices, it is possible that water utilities still enjoy economies of scope through sharing personnel, machines, buildings, and equipment in providing other infrastructure services along with water supply services.

Daily water production and daily water treatment capacities are negative and significant in the four models. ${ }^{27}$ Using groundwater as a source contributes to lower prices than either water purchase or surface water ${ }^{28}$ which is also consistent with the results in Table 5. Inefficiency, as measured by the estimated percentage of water loss, results in higher prices.

Water prices are higher in the Middle Atlantic and the South than the Southwest, while they are lower in the West. As in the results in Table 5, neither water rate regulations nor the LCV Index is significant.

\subsection{Monthly Water Charges per Ccf (Non-Residential, 500 Ccf)}

Table 7 shows the 3SLS results for monthly water charges per Cef (non-residential, $500 \mathrm{Ccf}$ ). All coefficients exhibit expected signs. $R^{2}$ ranges from about 0.18 to 0.19 ; and the $\chi^{2}$ values are very large, implying the overall significance of the estimated models. Total amounts of water sold are significant in the four models, with coefficients ranging from about 0.28 to 0.31 .

\footnotetext{
${ }^{26}$ On the basis of joint $\chi^{2}$ test results $\left[\chi^{2}(3)=1.26\right]$ in Model 2 and $\left[\chi^{2}(3)=1.28\right]$ in Model 4, there are no significant differences in water prices among different types of government ownership.

${ }^{27}$ The elasticity of water price with respect to daily water production capacity for water price ranges from about -0.10 to -0.11 , while the elasticity with respect to daily water treatment capacity ranges from about -0.21 to -0.24 .

${ }^{28}$ On the basis of joint $\chi^{2}$ test results $\left[\chi^{2}(2)=8.65\right]$ in Model $1,\left[\chi^{2}(2)=7.62\right]$ in Model 2, $\left[\chi^{2}(2)=10.50\right]$ in Model 3, and $\left[\chi^{2}(2)=9.37\right]$ in Model 4, in use of groundwater, water prices are significantly lower than in use of surface water.
} 
TABLE 6

District Ownership

Water Rate Regulation

$-0.0255$

$(0.093)$

$-0.0322$

$(0.064)$

0.1153

$(0.054)^{* *}$

0.0091

$(0.003)^{* * *}$

$-0.2139$

$(0.059)^{* * *}$

-0.1046 **

$(0.050)^{* *}$

per Ccf (Residential, $30 \mathrm{Ccf}$ )

Model 4

stimate

\begin{tabular}{lll} 
Std. Error) & (Std. Error) & (Std. Error) \\
\hline
\end{tabular}

$\begin{array}{lll}-0.5848 & -0.4985 & -0.5455 \\ (0.618) & (0.696) & (0.685)\end{array}$

$\begin{array}{lll}(0.618) & (0.696) & (0.685)\end{array}$

$\begin{array}{lll}0.2554_{* * *} & 0.2818 & 0.2812\end{array}$

$(0.077)^{* * *} \quad(0.077)^{* * *} \quad(0.082)^{* * *} \quad(0.082)^{* * *}$

$(0.050)^{* * *}$

0.1477

$(0.049)^{* * *}$

0.1663

$(0.050)^{* * *}$

0.1635

$(0.069)^{* * *}$

$-0.2277$

$-0.2411$

$-0.050)$

0.1600

$(0.071)^{* * *}$

$(0.072)^{* * *}$

$(0.073)^{* * *}$

$-0.1658$

$-0.0801$

$(0.118)$

(0.162)

0.0050

$(0.142)$

$-0.0320$

$(0.118)$

0.0101

$-0.0424$

(0.083)

$-0.0396$

$(0.096)$

$-0.0292$

$-0.0993$

(0.123)

$-0.0250$

$(0.147)$

$-0.0457$

0.1078

(0.066)

$(0.122)$

$-0.0083$

0.1078

0.1127

$-0.037$

$(0.053)^{* * *}$

$(0.056)^{* * *}$

(0.065)

n (Long-Term Debts)

0.0087

0.1070

$(0.003)^{* * *}$

$(0.003)^{* * *}$

0.0083

ln (Daily Water Treatment Capacity)

.2198

$-0.2307$

$(0.003)^{* * *}$

ln (Maximum Daily Water Production)

$(0.058)$

$(0.062)^{* * *}$

$-0.2352$

$-0.1006$

$(0.053)^{* *}$

$-0.1095$

$(0.052)^{* *}$ 


\begin{tabular}{|c|c|c|c|c|}
\hline $\begin{array}{l}\text { Dependent Variable: } \\
\text { In (Monthly Chargers per Ccf) }\end{array}$ & $\begin{array}{l}\frac{\text { Model 1 }}{\text { Estimate }} \\
\text { (Std. Error) }\end{array}$ & $\begin{array}{l}\frac{\text { Model 2 }}{\text { Estimate }} \\
\text { (Std. Error) }\end{array}$ & $\begin{array}{l}\frac{\text { Model 3 }}{\text { Estimate }} \\
\text { (Std. Error) }\end{array}$ & $\begin{array}{l}\frac{\text { Model 4 }}{\text { Estimate }} \\
\text { (Std. Error) }\end{array}$ \\
\hline Ground Water & $\begin{array}{l}-0.0019 \\
(0.001)^{* *}\end{array}$ & $\begin{array}{l}-0.0016 \\
(0.001)^{*}\end{array}$ & $\begin{array}{l}-0.0022 \\
(0.001)^{* *}\end{array}$ & $\begin{array}{l}-0.0020 \\
(0.001)^{* *}\end{array}$ \\
\hline Surface Water & $\begin{array}{l}-0.0003 \\
(0.001)\end{array}$ & $\begin{array}{l}-0.0001 \\
(0.001)\end{array}$ & $\begin{array}{l}-0.0004 \\
(0.001)\end{array}$ & $\begin{array}{l}-0.0003 \\
(0.001)\end{array}$ \\
\hline Water Loss & $\begin{array}{l}0.0095 \\
(0.003)^{* * *}\end{array}$ & $\begin{array}{l}0.0092 \\
(0.003)^{* * *}\end{array}$ & $\begin{array}{l}0.0092 \\
(0.003)^{* * *}\end{array}$ & $\begin{array}{l}0.0091 \\
(0.003)^{* * *}\end{array}$ \\
\hline LCV Index & $\begin{array}{c}0.0036 \\
(0.003)\end{array}$ & $\begin{array}{c}0.0032 \\
(0.003)\end{array}$ & $\begin{array}{c}0.0040 \\
(0.003)\end{array}$ & $\begin{array}{c}0.0036 \\
(0.003)\end{array}$ \\
\hline Doctrine of Prior Appropriation (Dummy) & $\begin{array}{l}0.4127 \\
(0.139)^{* * *}\end{array}$ & $(0.140)^{* * *}$ & & \\
\hline Doctrine of Prior Appropriation (Index) & & & $\begin{array}{l}0.1942 \\
(0.092)^{* *}\end{array}$ & $\begin{array}{c}0.1884 \\
(0.091)^{* *}\end{array}$ \\
\hline Middle Atlantic & $\begin{array}{l}0.4471 \\
(0.161)^{* * *}\end{array}$ & $\begin{array}{l}0.4289 \\
(0.164)^{* * *}\end{array}$ & $\begin{array}{c}0.2728 \\
(0.145)^{*}\end{array}$ & $\begin{array}{c}0.2531 \\
(0.148)^{*}\end{array}$ \\
\hline Midwest & $\begin{array}{r}0.1746 \\
(0.131)\end{array}$ & $\begin{array}{l}0.1646 \\
(0.132)\end{array}$ & $\begin{array}{c}0.0634 \\
(0.126)\end{array}$ & $\begin{array}{c}0.0540 \\
(0.126)\end{array}$ \\
\hline New England & $\begin{array}{c}0.2092 \\
(0.184)\end{array}$ & $\begin{array}{c}0.2016 \\
(0.184)\end{array}$ & $\begin{array}{c}0.0261 \\
(0.175)\end{array}$ & $\begin{array}{c}0.0190 \\
(0.175)\end{array}$ \\
\hline South & $\begin{array}{l}0.3281 \\
(0.148)^{* *}\end{array}$ & $\begin{array}{c}0.2957 \\
(0.152)^{* *}\end{array}$ & $\begin{array}{r}0.1619 \\
(0.127)\end{array}$ & $\begin{array}{c}0.1310 \\
(0.132)\end{array}$ \\
\hline West & $\begin{array}{l}-0.2204 \\
(0.099)^{* *}\end{array}$ & $\begin{array}{l}-0.2208 \\
(0.099)^{* *}\end{array}$ & $\begin{array}{l}-0.2381 \\
(0.106)^{* *}\end{array}$ & $\begin{array}{l}-0.2394 \\
(0.106)^{* *}\end{array}$ \\
\hline $\mathrm{N}$ & 259 & 259 & 259 & 259 \\
\hline$\chi^{2}$ value & 129.83 & 129.47 & 116.17 & 1162.26 \\
\hline Prob $>\chi^{2}$ & 0.000 & 0.000 & 0.000 & 0.000 \\
\hline$R^{2}$ & 0.2200 & 0.2151 & 0.1879 & 0.1858 \\
\hline
\end{tabular}


Some variables on institutional arrangements and characteristics of water utilities are significant. Under either the exclusive DPA rights system or the mixed system of DPA and riparian rights, water prices are significantly higher than under the system of exclusive riparian rights. Under the exclusive DPA rights system, water prices are higher than under either the mixed DPA and riparian rights system or the system of exclusive riparian rights. In addition, under the mixed system, water prices are higher than those under the system of exclusive riparian rights. These findings are consistent with the results in Table 6. Use of increasing block rates contributes to higher water prices for non-residential users than use of other pricing rates structures. When the water bill is combined with other bills, water prices are higher for non-residential users, probably for the same reasons found for monthly water charges per Ccf for residential users in Tables 5 and 6 . Under government ownership, even when different types of government ownership are accounted for, water prices do not significantly differ from those under private ownership. ${ }^{29}$ Long-term debts contribute to higher water prices, although coefficients are not large.

Several supply factors and characteristics are significant in explaining geographical differences in water prices across utilities. Large daily water production and daily water treatment capacities reduce water prices. ${ }^{30}$ Using groundwater contributes to lower water prices compared to surface water or purchased water. ${ }^{31}$ Water loss during water production, treatment, and delivery increases water prices.

As shown in Table 7, state environmental regulations and commitments, as measured by the LCV Index, contribute to higher water prices in the four models. But water rate regulations have no effect. Water prices are lower in the West than in the Southwest.

\subsection{Monthly Water Charges per Ccf (Non-Residential, 10,000 Ccf)}

Table 8 shows the 3SLS results for monthly water charges per Ccf (non-residential, $10,000 \mathrm{Ccf}$ ). All coefficients exhibit expected signs. $R^{2}$ ranges from about 0.24 to 0.26 ; and the $\chi^{2}$ values are very large, implying the overall significance of the estimated models. Total amounts of water sold are significant in the four models, with coefficients ranging from about 0.22 to 0.25 .

Compared with the results in Tables 5, 6, and 7, more institutional variables explain price differences in water prices across utilities. As shown in Models 3 and 4 of Table 8, under the exclusive DPA rights system, water prices are higher than under either the

\footnotetext{
${ }^{29}$ On the basis of joint $\chi^{2}$ test results $\left[\chi^{2}(3)=1.15\right]$ in Model 2 and $\left[\chi^{2}(3)=0.91\right]$ in Model 4, there are no significant differences in water prices among these types of government ownership.

${ }^{30}$ The elasticity of water price with respect to daily water production capacity ranges from abut -0.09 to -0.10 , while the elasticity of water price with respect to daily water treatment capacity ranges from about -0.25 to -0.27 .

${ }^{31}$ On the basis of joint $\chi^{2}$ test results $\left[\chi^{2}(2)=11.23\right]$ in Model $1,\left[\chi^{2}(2)=11.45\right]$ in Model 2, $\left[\chi^{2}(2)=14.37\right]$ in Model 3, and $\left[\chi^{2}(2)=14.55\right]$ in Model 4, in use of groundwater, water prices are significantly lower than in use of surface water.
} 
TABLE 7

\begin{tabular}{|c|c|c|c|c|}
\hline $\begin{array}{l}\text { Dependent Variable: } \\
\text { In (Monthly Chargers per Ccf) }\end{array}$ & $\begin{array}{l}\text { Model 1 } \\
\text { Estimate } \\
\text { (Std. Error) }\end{array}$ & $\begin{array}{l}\frac{\text { Model 2 }}{\text { Estimate }} \\
\text { (Std. Error) }\end{array}$ & $\begin{array}{l}\frac{\text { Model 3 }}{\text { Estimate }} \\
\text { (Std. Error) }\end{array}$ & $\begin{array}{l}\text { Model 4 } \\
\text { Estimate } \\
\text { (Std. Error) }\end{array}$ \\
\hline Constant & $\begin{array}{l}-0.7766 \\
(0.696)\end{array}$ & $\begin{array}{l}-0.7515 \\
(0.687)\end{array}$ & $\begin{array}{l}-1.0104 \\
(0.758)\end{array}$ & $\begin{array}{l}-0.9747 \\
(0.750)\end{array}$ \\
\hline $\ln ($ Water Sold) & $\begin{array}{c}0.2843 \\
(0.086)^{* * *}\end{array}$ & $\begin{array}{c}0.2814 \\
(0.086)^{* * *}\end{array}$ & $\begin{array}{c}0.3110 \\
(0.089)^{* * *}\end{array}$ & $\begin{array}{c}0.3081 \\
(0.090)^{* * *}\end{array}$ \\
\hline Increasing Block Rates (Non-Residential) & $\begin{array}{l}0.2100 \\
(0.060)^{* * *}\end{array}$ & $\begin{array}{l}0.2101 \\
(0.059)^{* * *}\end{array}$ & $\begin{array}{l}0.2080 \\
(0.060)^{* * *}\end{array}$ & $\begin{array}{l}0.2087 \\
(0.059)^{* * *}\end{array}$ \\
\hline Bills Combined & $\begin{array}{l}-0.2224 \\
(0.076)^{* * *}\end{array}$ & $\begin{array}{l}-0.2310 \\
(0.078)^{* * *}\end{array}$ & $\begin{array}{l}-0.2258 \\
(0.078)^{* * *}\end{array}$ & $\begin{array}{l}-0.2359 \\
(0.080)^{* * *}\end{array}$ \\
\hline Government Ownership & $\begin{array}{l}-0.0854 \\
(0.170)\end{array}$ & & $\begin{array}{l}-0.0767 \\
(0.175)\end{array}$ & \\
\hline City Ownership & & $\begin{array}{l}-0.0571 \\
(0.131)\end{array}$ & & $\begin{array}{l}-0.0568 \\
(0.134)\end{array}$ \\
\hline County Ownership & & $\begin{array}{r}0.0317 \\
(0.157)\end{array}$ & & $\begin{array}{l}0.0128 \\
(0.161)\end{array}$ \\
\hline District Ownership & & $\begin{array}{l}-0.0800 \\
(0.130)\end{array}$ & & $\begin{array}{l}-0.0844 \\
(0.134)\end{array}$ \\
\hline Water Rate Regulation & $\begin{array}{l}-0.0729 \\
(0.102)\end{array}$ & $\begin{array}{l}-0.0645 \\
(0.092)\end{array}$ & $\begin{array}{l}-0.0767 \\
(0.104)\end{array}$ & $\begin{array}{l}-0.0725 \\
(0.094)\end{array}$ \\
\hline Seasonal Peak Rates & $\begin{array}{l}-0.0441 \\
(0.069)\end{array}$ & $\begin{array}{l}-0.0512 \\
(0.069)\end{array}$ & $\begin{array}{l}-0.0518 \\
(0.071)\end{array}$ & $\begin{array}{l}-0.0573 \\
(0.071)\end{array}$ \\
\hline Provision of Other Infrastructure Services & $\begin{array}{c}0.0958 \\
(0.060)\end{array}$ & $\begin{array}{r}0.0913 \\
(0.059)\end{array}$ & $\begin{array}{c}0.0868 \\
(0.061)\end{array}$ & $\begin{array}{c}0.0836 \\
(0.061)\end{array}$ \\
\hline ln (Long-Term Debts) & $\begin{array}{l}0.0093 \\
(0.003)^{* * *}\end{array}$ & $(0.003)^{* * *}$ & $(0.003)^{* * *}$ & $(0.003)^{* * *}$ \\
\hline In (Daily Water Treatment Capacity) & $\begin{array}{l}-0.2508 \\
(0.065)^{* * *}\end{array}$ & $\begin{array}{l}-0.2509 \\
(0.064)^{* * *}\end{array}$ & $\begin{array}{l}-0.2656 \\
(0.067)^{* * *}\end{array}$ & $\begin{array}{l}-0.2654 \\
(0.067)^{* * *}\end{array}$ \\
\hline In (Maximum Daily Water Production) & $\begin{array}{l}-0.0920 \\
(0.055)^{*}\end{array}$ & $\begin{array}{l}-0.0914 \\
(0.055)^{*}\end{array}$ & $\begin{array}{l}-0.1010 \\
(0.057)^{*}\end{array}$ & $\begin{array}{l}-0.1007 \\
(0.057)^{*}\end{array}$ \\
\hline
\end{tabular}




\begin{tabular}{|c|c|c|c|c|}
\hline $\begin{array}{l}\text { Dependent Variable: } \\
\text { In (Monthly Chargers per Ccf) }\end{array}$ & $\begin{array}{l}\text { Model 1 } \\
\text { Estimate } \\
\text { (Std. Error) }\end{array}$ & $\begin{array}{l}\frac{\text { Model 2 }}{\text { Estimate }} \\
\text { (Std. Error) }\end{array}$ & $\begin{array}{l}\frac{\text { Model 3 }}{\text { Estimate }} \\
\text { (Std. Error) }\end{array}$ & $\begin{array}{c}\text { Model 4 } \\
\text { Estimate } \\
\text { (Std. Error) }\end{array}$ \\
\hline Ground Water & $\begin{array}{l}-0.0026 \\
(0.001)^{* * *}\end{array}$ & $\begin{array}{l}-0.0026 \\
(0.001)^{* *}\end{array}$ & $\begin{array}{l}-0.0032 \\
(0.001)^{* * *}\end{array}$ & $\begin{array}{l}-0.0031 \\
(0.001)^{* * *}\end{array}$ \\
\hline Surface Water & $\begin{array}{l}-0.0007 \\
(0.001)\end{array}$ & $\begin{array}{l}-0.0006 \\
(0.001)\end{array}$ & $\begin{array}{l}-0.0010 \\
(0.001)\end{array}$ & $\begin{array}{l}-0.0009 \\
(0.001)\end{array}$ \\
\hline Water Loss & $\begin{array}{l}0.0079 \\
(0.003)^{* * *}\end{array}$ & $\begin{array}{l}0.0075 \\
(0.003)^{* * *}\end{array}$ & $\begin{array}{l}0.0079 \\
(0.003)^{* * *}\end{array}$ & $\begin{array}{l}0.0076 \\
(0.003)^{* * *}\end{array}$ \\
\hline LCV Index & $\begin{array}{l}0.0059 \\
(0.003)^{* *}\end{array}$ & $\begin{array}{l}0.0060 \\
(0.003)^{* *}\end{array}$ & $\begin{array}{l}0.0083 \\
(0.003)^{* * *}\end{array}$ & $\begin{array}{l}0.0083 \\
(0.003)^{* * *}\end{array}$ \\
\hline Doctrine of Prior Appropriation (Dummy) & $\begin{array}{l}0.2695 \\
(0.154)^{*}\end{array}$ & $\begin{array}{l}0.2676 \\
(0.155)^{*}\end{array}$ & & \\
\hline Doctrine of Prior Appropriation (Index) & & & $\begin{array}{l}0.2382 \\
(0.010)^{* *}\end{array}$ & $\begin{array}{l}0.2340 \\
(0.100)^{* *}\end{array}$ \\
\hline Middle Atlantic & $\begin{array}{c}0.0942 \\
(0.179)\end{array}$ & $\begin{array}{c}0.0864 \\
(0.182)\end{array}$ & $\begin{array}{r}0.0431 \\
(0.157)\end{array}$ & $\begin{array}{c}0.0351 \\
(0.160)\end{array}$ \\
\hline Midwest & $\begin{array}{l}-0.0400 \\
(0.145)\end{array}$ & $\begin{array}{c}-0.0509 \\
(0.146)\end{array}$ & $\begin{array}{l}-0.0612 \\
(0.135)\end{array}$ & $\begin{array}{c}-0.0730 \\
(0.136)\end{array}$ \\
\hline New England & $\begin{array}{l}-0.1122 \\
(0.204)\end{array}$ & $\begin{array}{l}-0.1194 \\
(0.204)\end{array}$ & $\begin{array}{l}-0.2036 \\
(0.189)\end{array}$ & $\begin{array}{l}-0.2110 \\
(0.189)\end{array}$ \\
\hline South & $\begin{array}{r}0.1165 \\
(0.165)\end{array}$ & $\begin{array}{r}0.0992 \\
(0.170)\end{array}$ & $\begin{array}{r}0.1240 \\
(0.139)\end{array}$ & $\begin{array}{c}0.1078 \\
(0.144)\end{array}$ \\
\hline West & $\begin{array}{l}-0.3151 \\
(0.110)^{* * *}\end{array}$ & $\begin{array}{l}-0.3138 \\
(0.110)^{* * *}\end{array}$ & $\begin{array}{l}-0.3790 \\
(0.116)^{* * *}\end{array}$ & $\begin{array}{l}-0.3763 \\
(0.115)^{* * *}\end{array}$ \\
\hline $\mathrm{N}$ & 259 & 259 & 259 & 259 \\
\hline$\chi^{2}$ value & 104.46 & 105.74 & 102.58 & 103.70 \\
\hline Prob $>\chi^{2}$ & 0.000 & 0.000 & 0.000 & 0.000 \\
\hline$R^{2} \quad \sim$ & 0.1890 & 0.1921 & 0.1825 & 0.1858 \\
\hline
\end{tabular}


mixed system of both DPA and riparian rights or the system of exclusive riparian rights. Under the mixed system, water prices are higher than under the exclusive riparian rights system. Use of increasing block rates, provision of other infrastructure services, and longterm debts lead to higher water prices. The water bill combined with other bills contributes to lower prices. But under government ownership, even when different types of ownership are considered, water prices are not much different than under private ownership. $^{32}$

Daily water treatment capacity is a significant factor to lowering water prices, but daily water production capacity is not. ${ }^{33}$ Water sources are important in explaining geographical differences in water prices and are consistent with the results in Tables 5, 6, and 7. Groundwater is less expensive than surface water or purchased water. ${ }^{34}$

As shown in Table 8, water rate regulations contribute to lower water prices, while state environmental regulations and commitments increase water prices. Water prices in the West are lower than in the Southwest.

\subsection{Summary}

This paper found that several institutional factors and characteristics in water utilities significantly affect water prices for both residential and non-residential users. Whether water utilities produce, treat, and deliver water under the DPA rights or the riparian rights system is a contributing factor in explaining geographical variations in water prices. Water prices are higher under DPA systems than under riparian rights systems.

When the water bill is combined with other bills, water prices decrease. Use of increasing block rates contributes to higher prices compared with other pricing rate structures, such as uniform rates and decreasing block rates. The provision of other infrastructure services by water utilities contributes to higher water prices, implying that utilities transfer all or some costs of providing other services to water prices. Water utilities with long-term debts increase their water prices. There is little difference in water prices between government and private ownership. This finding is consistent even when three types of government ownership are accounted for.

Some supply factors and characteristics are important in explaining price differences across water utilities. In particular, using groundwater as a source contributes to lower prices than using either surface water or purchased water. Large daily water production and daily water treatment capacities decrease water prices. Water loss, which represents

\footnotetext{
${ }^{32}$ On the basis of joint $\chi^{2}$ test results $\left[\chi^{2}(3)=3.93\right]$ in Model 2 and $\left[\chi^{2}(3)=3.54\right]$ in Model 4, there are no significant differences in water prices among these types of government ownership.

${ }^{33}$ The elasticity of water price with respect to daily water treatment capacity ranges from -0.19 to 0.20 .

${ }^{34}$ On the basis of joint $\chi^{2}$ test results $\left[\chi^{2}(2)=14.10\right]$ in Model $1,\left[\chi^{2}(2)=14.66\right]$ in Model 2, $\left[\chi^{2}(2)=17.28\right]$ in Model 3 , and $\left[\chi^{2}(2)=17.74\right]$ in Model 4, in use of groundwater, water prices are significantly lower than in use of surface water.
} 
TABLE 8

District Ownership

Water Rate Regulation

Seasonal Peak Rates

Provision of Other Infrastructure Services

$(0.118)^{* *}$

$-0.1184$

(0.080)

0.1631

$(0.069)^{* *}$

0.0124

$(0.004)^{*}$

$-0.1934$

$(0.075)^{* * *}$

$-0.0960$

(0.064)

\begin{tabular}{|c|c|c|}
\hline Model 2 & Model 3 & Model 4 \\
\hline $\begin{array}{l}\overline{\text { Estimate }} \\
\text { (Std. Error) }\end{array}$ & $\begin{array}{l}\overline{\text { Estimate }} \\
\text { (Std. Error) }\end{array}$ & $\begin{array}{l}\overline{\text { Estimate }} \\
\text { (Std. Error) }\end{array}$ \\
\hline-0.1866 & -0.5396 & -0.3692 \\
\hline$(0.774)$ & $(0.863)$ & $(0.844)$ \\
\hline 0.2180 & 0.2527 & 0.2358 \\
\hline$(0.098)^{* *}$ & $(0.102)^{* * *}$ & $(0.102)^{* *}$ \\
\hline 0.3075 & 0.3019 & 0.3053 \\
\hline$(0.068)^{* * *}$ & $(0.068)^{* * *}$ & $(0.067)^{* * *}$ \\
\hline-0.2450 & -0.2616 & -0.2458 \\
\hline \multirow[t]{3}{*}{$(0.090)^{* * *}$} & $(0.089)^{* * *}$ & $(0.091)^{* * *}$ \\
\hline & -0.2439 & \\
\hline & $(0.202)$ & \\
\hline-0.2396 & & -0.2453 \\
\hline$(0.150)$ & & $(0.153)$ \\
\hline-0.0605 & & -0.0840 \\
\hline$(0.181)$ & & $(0.184)$ \\
\hline-0.1919 & & -0.1994 \\
\hline$(0.150)$ & & $(0.153)$ \\
\hline-0.2098 & -0.2408 & -0.2210 \\
\hline$(0.106)^{* *}$ & $(0.120)^{* *}$ & $(0.107)^{* *}$ \\
\hline-0.1352 & -0.1279 & -0.1432 \\
\hline$(0.080)^{*}$ & $(0.081)$ & $(0.081)^{*}$ \\
\hline 0.1587 & 0.1535 & 0.1508 \\
\hline$(0.070)^{* *}$ & $(0.071)^{* *}$ & $(0.069)^{* *}$ \\
\hline 0.0121 & 0.0120 & 0.0118 \\
\hline$(0.004)^{* * *}$ & $(0.004)^{* * *}$ & $(0.004)^{* * *}$ \\
\hline-0.1919 & -0.2029 & -0.1992 \\
\hline$(0.074)^{* * *}$ & $(0.077)^{* * *}$ & $(0.076)^{* * *}$ \\
\hline-0.0895 & -0.1041 & -0.0969 \\
\hline$(0.063)$ & $(0.066)$ & $(0.065)$ \\
\hline
\end{tabular}




\begin{tabular}{|c|c|c|c|c|}
\hline $\begin{array}{l}\text { Dependent Variable: } \\
\text { In (Monthly Chargers per Ccf) }\end{array}$ & $\begin{array}{l}\frac{\text { Model 1 }}{\text { Estimate }} \\
\text { (Std. Error) }\end{array}$ & $\begin{array}{l}\frac{\text { Model 2 }}{\text { Estimate }} \\
\text { (Std. Error) }\end{array}$ & $\begin{array}{l}\frac{\text { Model } 3}{\text { Estimate }} \\
\text { (Std. Error) }\end{array}$ & $\begin{array}{l}\text { Model } 4 \\
\text { Estimate } \\
\text { (Std. Error) }\end{array}$ \\
\hline Ground Water & $\begin{array}{l}-0.0037 \\
(0.001)^{* * *}\end{array}$ & $\begin{array}{l}-0.0036 \\
(0.001)^{* * *}\end{array}$ & $\begin{array}{l}-0.0042 \\
(0.001)^{* * *}\end{array}$ & $\begin{array}{l}-0.0041 \\
(0.001)^{* * *}\end{array}$ \\
\hline Surface Water & $\begin{array}{l}-0.0013 \\
(0.001)\end{array}$ & $\begin{array}{l}-0.0012 \\
(0.001)\end{array}$ & $\begin{array}{l}-0.0016 \\
(0.001)\end{array}$ & $\begin{array}{l}-0.0015 \\
(0.001)\end{array}$ \\
\hline Water Loss & $\begin{array}{l}-0.0005 \\
(0.003)\end{array}$ & $\begin{array}{l}-0.0008 \\
(0.003)\end{array}$ & $\begin{array}{l}-0.0008 \\
(0.003)\end{array}$ & $\begin{array}{l}-0.0011 \\
(0.003)\end{array}$ \\
\hline LCV Index & $\begin{array}{c}0.0060 \\
(0.003)^{*}\end{array}$ & $\begin{array}{c}0.0058 \\
(0.003)^{*}\end{array}$ & $\begin{array}{c}0.0084 \\
(0.004)^{* *}\end{array}$ & $\begin{array}{c}0.0082 \\
(0.004)^{* *}\end{array}$ \\
\hline Doctrine of Prior Appropriation (Dummy) & $\begin{array}{c}0.2584 \\
(0.173)\end{array}$ & $\begin{array}{r}0.2329 \\
(0.172)\end{array}$ & & \\
\hline Doctrine of Prior Appropriation (Index) & & & $\begin{array}{l}0.2351 \\
(0.112)^{* *}\end{array}$ & $\begin{array}{l}0.2183 \\
(0.111)^{* *}\end{array}$ \\
\hline Middle Atlantic & $\begin{array}{l}0.1420 \\
(0.200)\end{array}$ & $\begin{array}{l}0.0808 \\
(0.202)\end{array}$ & $\begin{array}{r}0.1008 \\
(0.177)\end{array}$ & $\begin{array}{r}0.0475 \\
(0.179)\end{array}$ \\
\hline Midwest & $\begin{array}{l}-0.1435 \\
(0.162)\end{array}$ & $\begin{array}{l}-0.1767 \\
(0.161)\end{array}$ & $\begin{array}{l}-0.1602 \\
(0.152)\end{array}$ & $\begin{array}{l}-0.1890 \\
(0.152)\end{array}$ \\
\hline New England & $\begin{array}{l}-0.2107 \\
(0.228)\end{array}$ & $\begin{array}{l}-0.2503 \\
(0.227)\end{array}$ & $\begin{array}{l}-0.2943 \\
(0.213)\end{array}$ & $\begin{array}{l}-0.3246 \\
(0.210)\end{array}$ \\
\hline South & $\begin{array}{r}0.0015 \\
(0.185)\end{array}$ & $\begin{array}{l}-0.0713 \\
(0.189)\end{array}$ & $\begin{array}{c}0.0164 \\
(0.156)\end{array}$ & $\begin{array}{l}-0.0482 \\
(0.160)\end{array}$ \\
\hline West & $\begin{array}{l}-0.3123 \\
(0.123)^{* * *}\end{array}$ & $\begin{array}{l}-0.3207 \\
(0.122)^{* * *}\end{array}$ & $\begin{array}{l}-0.3777 \\
(0.130)^{* * *}\end{array}$ & $\begin{array}{l}-0.3834 \\
(0.128)^{* * *}\end{array}$ \\
\hline $\mathrm{N}$ & 259 & 259 & 259 & 259 \\
\hline$\chi^{2}$ value & 123.02 & 128.43 & 120.98 & 126.53 \\
\hline Prob $>\chi^{2}$ & 0.000 & 0.000 & 0.000 & 0.000 \\
\hline$R^{2}$ & 0.2465 & 0.2600 & 0.2417 & 0.2572 \\
\hline
\end{tabular}


inefficiency in the operation and maintenance of a water supply system, has positive influences on water prices.

Water rate regulation by state public utility commissions has some negative effects on water prices. Environmental regulations and commitments at the state level contribute to higher water prices, especially for non-residential users.

\section{CONCLUSIONS WITH STUDY LIMITATIONS}

Infrastructure services contribute to social welfare through facilitating business activities in the private sector and improving quality-of-life environments. Water supply services are one major type of infrastructure service, but water prices differ considerably across regions and localities. The purpose of this paper has been to explain which elements significantly contribute to geographical differences in water prices. To do so, a conceptual model was developed that takes into account four major categories of relevant variables in influencing water prices: (1) institutional arrangements and characteristics of water utilities, (2) government regulations at the state and local level (including environmental, health, and safety regulations), (3) supply factors and characteristics, and (4) natural environments and local characteristics (including natural endowments and physical geography). For empirical analysis, the price and demand equations for water supply under a system of simultaneous structural equations were used.

Several institutional factors and characteristics are important in explaining geographical differences in water prices, such as DPA rights versus riparian rights systems, pricing rate structures, combination of the water bill with other bills, and provision of other infrastructure services. Water rate regulations by state public utility commissions also have some negative effects on water prices. State-level environmental regulations and commitments contribute to higher water prices, especially for non-residential users.

This paper has some limitations when analyzing which elements significantly contribute to geographical variations in water prices. First, the analysis could not account for the quality of a water supply, mainly because of data unavailability. Therefore, whether (and how) institutional arrangements and characteristics of water utilities influence geographical differences in the quality and reliability of water supply services warrants further examination. Second, some data also are not available for empirical analysis. For example, local governments enforce the environmental standards and regulations on infrastructure services imposed by federal and state governments, but some local governments also set additional standards and regulations. These additional activities by local governments may also influence water prices, but these were not included because of data unavailability. In addition, the LCV Index was employed as a proxy for environmental regulations and commitments at the state level. But the Index may not be complete, as it was constructed from voting records on environmental bills by each state's House and Senate delegations (Levinson 1999). 
The Review of Regional Studies, Vol. 37, No. 2, 2007, pp. 207 - 250

\section{REFERENCES}

American Water Works Association/Raftelis Financial Consulting, 2005. 2004 Water and Wastewater Rate Survey Results. Denver, CO.

Ansari, M.I., D.V. Gordon, and C. Akuamoah, 1997. "Keynes Versus Wagner: Public Expenditure and National Income for the Three African Countries," Applied Economics 29, 543-550.

Anwar, M.S., S. Davies, and R.K. Sampath, 1996. "Causality Between Government Expenditure and Economic Growth: An Examination Using Cointegration Technique," Public Finance 51, 166-184.

Aschauer, D.A., 1989. “Is Public Expenditure Productive?" Journal of Monetary Economics 23, 177-200.

Averch, H. and L.O. Johnson, 1962. "Behavior of the Firm Under Regulatory Constraint," American Economic Review 52, 1052-1069.

Bae, S., 2005. "Explaining the Water Supply System in the United States and France: A Historical Institutional Analysis," Modern Society and Public Administration 15(2), 121-141.

Barkatullah, N., 2002. "OLS and Instrumental Variable Price Elasticity Estimates for Water in Mixed Effect Model Under a Multipart Tariff Structure," London Economics. Available at www.londecon.co.uk/le/publications/working_papers_and_ briefs. shtml, May 2006.

Bel, G. and A. Miralles, 2003. "Factors Influencing the Privatization of Urban Solid Waste Collection in Spain," Urban Studies 40, 1323-1334.

Bruggink, T.H., 1982. "Public Versus Regulated Private Enterprises in the Municipal Water Industry: A Comparison of Operating Costs," Quarterly Review of Economics and Business 22, 111-125.

Bureau of Land Management, 2007. Western States' Water Laws. U.S. Department of the Interior. Available at www.blm.gov/nstc/WaterLaws, June.

Duerksen, C.J., 1983. Environmental Regulation of Industrial Plant Siting: How to Make It Work Better. Washington, D.C.: Conservation Foundation.

Feigenbaum, S. and R. Teeples, 1983. "Public Versus Private Water Delivery: A Hedonic Cost Approach," Review of Economics and Statistics 65, 672-678.

Fund for Renewable Energy and the Environment, 1987. The State of the States. Washington, D.C.: FREE.

Gopalakrishnan, C., 1973. "The Doctrine of Prior Appropriation and Its Impact on Water Development: A Critical Survey," American Journal of Economics and Sociology 32(1), 61-72.

Hall, B. and M.L. Kerr, 1991. 1991-1992 Green Index: A State-by-State Guide to the Nation's Environmental Health. Washington, D.C.: Island Press.

Halvorsen, R., 1975. "Residential Demand for Electric Energy," Review of Economics and Statistics 57, 12-18.

Haughwout, A.F., 2001. "Infrastructure and Social Welfare in Metropolitan America," Economic Policy Review, 1-16. Federal Reserve Bank of New York. 
Hewitt, J.A., 2000. "An Investigation into the Reasons Why Water Utilities Choose Particular Residential Rate Structures," in A. Dinar (ed.), The Political Economy of Water Pricing Reforms. New York: Oxford University Press.

Hirschman, A.O., 1958. "Investment Choices and Strategies," in The Strategy of Economic Development. New Haven: Yale University Press.

Hobbs, E., 2003. "Low Rates, Needed Repairs Lure 'Big Water' to Uncle Sam's Plumbing" (February 12) Center for Public Integrity.

Hutson, S.S., N.L. Barber, J.F. Kenny, K.S. Linsey, D.S. Lumia, and M.A. Maupin, 2004. Estimated Use of Water in the United States in 2000. U.S. Geological Survey: Reston, VA.

Institute for Southern Studies, 1994. Green and Gold. Durham, N.C.

Joassart-Marcelli, P. and J. Musso, 2005. "Municipal Service Provision Choices within a Metropolitan Area," Urban Affairs Review 40, 492-519.

Kennedy, P., 2001. A Guide to Econometrics ( $4^{\text {th }}$ ed.). Cambridge, MA: The MIT Press.

Kessides, C., 1996. "A Review of Infrastructure's Impact on Economic Development," in D.F. Batten and C. Karlsson (eds.), Infrastructure and the Complexity of Economic Development. New York: Springer.

Levinson, A., 1999. "An Industry-Adjusted Index of State Environmental Compliance Costs," (June 11-12) National Bureau of Economic Research (NBER) and Fondazione Eni Enrico Mattei (FEEM) Conference on the Distributional and Behavioral Effects of Environmental Policy. Milan, Italy.

Melchelson, A.M., J.F. Booker, and P. Person, 2000. "Expectations in Water-Right Prices," Water Resources Development 16(2), 209-219.

Merrett, S., 1997. "Effective Demand and the Price of Water," in Introduction to the Economics of Water Resources: An International Perspective. New York: Rowan \& Littlefield Publishers.

Molotch, H., 1976. "The City as a Growth Machine: Toward a Political Economy of Place," American Journal of Sociology 82(2), 309-332.

Molotch, H. and J. Logan, 1984. "Tensions in the Growth Machine: Overcoming Resistance to Value-Free Development," Social Problems 31(5), 483-499.

Park, W.K., 1996. "Wagner's Law Vs. Keynesian Paradigm: The Korean Experience," Public Finance 51, 71-91.

Renwick, M., R. Green, and C. McCorkle, 1998. Measuring the Price Responsiveness of Residential Water Demand in California's Urban Areas. Sacramento: California Department of Water Resources.

Renzetti, S., 2000. "An Empirical Perspective on Water Pricing Reforms," in A. Dinar (ed.), The Political Economy of Water Pricing Reforms. New York: Oxford University Press.

Renzetti, S. and D. Dupont, 2004. "The Performance of Municipal Water Utilities: Evidence on the Role of Ownership," Journal of Toxicology and Environmental Health Part A 67, 1861-1878.

Saal, D.S. and D. Parker, 2000. "The Impact of Privatization and Regulation on the Water and Sewerage Industry in England and Wales: A Translog Cost Function Model," Managerial and Decision Economics 21, 253-268. 
Schneider, M., 1992. "Undermining the Growth Machine: The Missing Link Between Local Economic Development and Fiscal Payoffs," Journal of Politics 54(1), 214230.

Shaw, W.D., 2005. Water Resource Economics and Policy: An Introduction. Northampton, MA: Edward Elgar.

Shih, J.S., H. Harrington, W.A. Pizer, and K. Gillingham, 2004. Economies of Scale and Technical Efficiency in Community Water Systems. Washington, D.C.; Resources for the Future.

Singh, B. and B.S. Sahni, 1984. "Causality Between Public Expenditure and National Income," Review of Economics and Statistics 66, 630-644.

Tarr, J.A., 1984. "The Evolution of the Urban Infrastructure in the Nineteenth and Twentieth Centuries," in R. Hanson (ed.), Perspectives on Urban Infrastructure. Washington, D.C.: National Academy Press.

, 1985. "Building the Urban Infrastructure in the Nineteenth Century: An Introduction," in Infrastructure and Urban Growth in the Nineteenth Century. Chicago: Public Works Historical Society.

Teeples, R. and D. Glyer, 1987. "Cost of Water Delivery Systems: Specification and Ownership Effects," Review of Economics and Statistics 69, 399-408.

Verbeek, M., 2000. A Guide to Modern Econometrics. New York: John Wiley \& Sons, Ltd.

Walls, M., M. Macauley, and S. Anderson, 2005. "Private Markets, Contracts, and Government Provision: What Explains the Organization of Local Waste and Recycling Markets?" Urban Affairs Review 40, 590-613.

World Bank, 1994. World Development Report 1994: Infrastructure for Development. Washington, D.C.

Zellner, A. and H. Theil, 1962. "Three-Stage Least Squares: Simultaneous Estimation of Simultaneous Equations," Econometrica 30(1), 54-78. 
APPENDIX TABLE 1

District Ownership

Water Rate Regulation

Seasonal Peak Rates

Provision of Other Infrastructure Services

ln (Long-Term Debts)

\section{Model 1}

Estimate

Ccf (Residential, $10 \mathrm{Cc}$ )

Dependent Variable:

\section{Model 4}

In (Monthly Chargers per Ccf)

$\ln$ (Water Sold)

\begin{tabular}{cccc}
1.7081 & 1.5752 & 2.0405 & 1.9085 \\
$(0.358)^{* * *}$ & $(0.376)^{* * *}$ & $(0.348)^{* * *}$ & $(0.365)^{* * *}$ \\
-0.0498 & -0.0471 & -0.0375 & -0.0357 \\
$(0.038)$ & $(0.038)$ & $(0.040)$ & $(0.040)$ \\
-0.0391 & -0.0379 & -0.0054 & -0.0054 \\
$(0.044)$ & $(0.045)$ & $(0.043)$ & $(0.044)$ \\
-0.1396 & -0.1399 & 0.1411 & -0.1355 \\
$(0.063)^{* *}$ & $(0.067)^{* *}$ & $(0.066)^{* *}$ & $(0.068)^{* *}$ \\
-0.3609 & & -0.3833 & \\
$(0.130)^{* * *}$ & & $(0.132)^{* * *}$ & \\
& -0.2171 & & -0.2557 \\
& $(0.149)$ & & $(0.138)^{*}$ \\
& -0.1582 & & -0.1942 \\
& $(0.163)$ & & $(0.157)$ \\
0.0052 & -0.1547 & & -0.1789 \\
$(0.089)$ & $(0.145)$ & & $(0.137)$ \\
-0.0370 & -0.0747 & -0.0268 & 0.0412 \\
$(0.068)$ & $(0.068)$ & $(0.071)$ & $(0.086)$ \\
0.0748 & 0.0664 & 0.0775 & 0.0700 \\
$(0.058)$ & $(0.059)$ & $(0.060)$ & $(0.060)$ \\
0.0077 & 0.0069 & 0.0071 & 0.0064 \\
$(0.003)^{* * *}$ & $(0.003)^{* *}$ & $(0.003)^{* * *}$ & $(0.003)^{* *}$ \\
0.0122 & 0.0048 & 0.0022 & -0.0048 \\
$(0.050)$ & $(0.050)$ & $(0.052)$ & $(0.052)$ \\
-0.0490 & -0.0430 & -0.0527 & -0.0466 \\
$(0.061)$ & $(0.060)$ & $(0.064)$ & $(0.062)$ \\
\hline & & &
\end{tabular}

ln (Daily Water Treatment Capacity)

ln (Maximum Daily Water Production)

$(0.061)$

(0.060)

(0.064) 


\begin{tabular}{|c|c|c|c|c|}
\hline $\begin{array}{l}\text { Dependent Variable: } \\
\text { In (Monthly Chargers per Ccf) }\end{array}$ & $\begin{array}{l}\frac{\text { Model 1 }}{\text { Estimate }} \\
\text { (Std. Error) }\end{array}$ & $\begin{array}{l}\frac{\text { Model } 2}{\text { Estimate }} \\
\text { (Std. Error) }\end{array}$ & $\begin{array}{l}\text { Model 3 } \\
\text { Estimate } \\
\text { (Std. Error) }\end{array}$ & $\begin{array}{c}\text { Model } 4 \\
\text { Estimate } \\
\text { (Std. Error) }\end{array}$ \\
\hline Ground Water & $\begin{array}{l}-0.0034 \\
(0.001)^{* * *}\end{array}$ & $\begin{array}{l}-0.0033 \\
(0.001)^{* * *}\end{array}$ & $\begin{array}{l}-0.0035 \\
(0.001)^{* * *}\end{array}$ & $\begin{array}{l}-0.0034 \\
(0.001)^{* * *}\end{array}$ \\
\hline Surface Water & $\begin{array}{l}-0.0017 \\
(0.001)^{* *}\end{array}$ & $\begin{array}{l}-0.0017 \\
(0.001)^{* *}\end{array}$ & $\begin{array}{l}-0.0016 \\
(0.001)^{* *}\end{array}$ & $\begin{array}{l}-0.0016 \\
(0.001)^{* *}\end{array}$ \\
\hline Water Loss & $\begin{array}{l}0.0058 \\
(0.002)^{* *}\end{array}$ & $\begin{array}{l}0.0058 \\
(0.002)^{* * *}\end{array}$ & $\begin{array}{l}0.0051 \\
(0.003)^{* *}\end{array}$ & $\begin{array}{l}0.0520 \\
(0.003)^{* *}\end{array}$ \\
\hline LCV Index & $\begin{array}{l}0.0057 \\
(0.002)^{* * *}\end{array}$ & $\begin{array}{c}0.0053 \\
(0.002)^{* *}\end{array}$ & $\begin{array}{c}0.0040 \\
(0.003)\end{array}$ & $\begin{array}{r}0.0037 \\
(0.003)\end{array}$ \\
\hline Doctrine of Prior Appropriation (Dummy) & $\begin{array}{l}0.4244 \\
(0.140)^{* * *}\end{array}$ & $\begin{array}{l}0.4099 \\
(0.145)^{* * *}\end{array}$ & & \\
\hline Doctrine of Prior Appropriation (Index) & & & $\begin{array}{r}0.0871 \\
(0.095)\end{array}$ & $\begin{array}{l}0.0866 \\
(0.095)\end{array}$ \\
\hline Middle Atlantic & $\begin{array}{c}0.3592 \\
(0.164)^{* *}\end{array}$ & $\begin{array}{c}0.3278 \\
(0.169)^{* *}\end{array}$ & $\begin{array}{c}0.1201 \\
(0.128)\end{array}$ & $\begin{array}{c}0.0912 \\
(0.130)\end{array}$ \\
\hline Midwest & $\begin{array}{r}0.0768 \\
(0.135)\end{array}$ & $\begin{array}{c}0.0574 \\
(0.141)\end{array}$ & $\begin{array}{l}-0.0889 \\
(0.1150)\end{array}$ & $\begin{array}{l}-0.1021 \\
(0.119)\end{array}$ \\
\hline New England & $\begin{array}{c}0.1094 \\
(0.186)\end{array}$ & $\begin{array}{r}0.0857 \\
(0.190)\end{array}$ & $\begin{array}{l}-0.1044 \\
(0.168)\end{array}$ & $\begin{array}{l}-0.1225 \\
(0.169)\end{array}$ \\
\hline South & $\begin{array}{c}0.3395 \\
(0.157)^{* *}\end{array}$ & $\begin{array}{c}0.3029 \\
(0.163)^{*}\end{array}$ & $\begin{array}{c}0.0510 \\
(0.109)\end{array}$ & $\begin{array}{c}0.0222 \\
(0.112)\end{array}$ \\
\hline West & $\begin{array}{l}-0.1279 \\
(0.089)\end{array}$ & $\begin{array}{l}-0.1296 \\
(0.090)\end{array}$ & $\begin{array}{l}-0.0938 \\
(0.112)\end{array}$ & $\begin{array}{l}-0.1010 \\
(0.112)\end{array}$ \\
\hline $\mathrm{N}$ & 259 & 259 & 259 & 259 \\
\hline F value & 6.76 & 5.80 & 6.26 & 5.38 \\
\hline Prob $>$ F & 0.000 & 0.000 & 0.000 & 0.000 \\
\hline - 50 & 0.3037 & 0.2976 & 0.2757 & 0.2722 \\
\hline
\end{tabular}


APPENDIX TABLE 2

District Ownership

Water Rate Regulation

$-0.0319$

(0.105)

$-0.0282$

Model 1

Estimate

\section{Model 2}

Estimate

Model 3

(Std. Error)

Std. Error)

Model 4

In (Monthly Chargers per Ccf)

In (Water Sold)

$(0.381)^{*}$

1.1428

\begin{tabular}{ll} 
(Std. Error) & (Std. Error) \\
\hline 1.5589 & 1.4434
\end{tabular}

$-0.0127$

$(0.391)^{* * *}$

$(0.387)$

Increasing Block Rates (Residential)

Bills Combined

0.1290

$(0.038)$

$(0.374)$

0.0024

$(0.048)^{* * *}$

0.1275

$-0.1902$

$(0.049)^{* * *}$

(0.038)

(0.039)

$(0.060)^{* * *}$

$-0.1899$

$(0.1647)^{* * *}$

0.1593

$-0.3482$

$(0.069)^{* * *}$

$-0.1931$

$(0.048)$

Government Ownership

$(0.148)^{* *}$

$-0.3657$

City Ownership

Seasonal Peak Rates

Provision of Other Infrastructure Services

(0.071)

0.1201

$(0.061)^{* *}$

0.0073

$(0.003)^{* *}$

$-0.1875$

$(0.152)^{* *}$

$(0.071)^{* * *}$

ln (Long-Term Debts)

$(0.163)$
-0.0515

$-0.2250$

(0.153)

(0.178)

$(0.173)$

$-0.1323$

$-0.1558$

(0.159)

(0.153)

0.0456

$-0.0638$

0.0104

(0.102)

$(0.100)$

$-0.0387$

$-0.0213$

$-0.0334$

$(0.072)$

(0.074)

(0.075)

$\begin{array}{lll}0.1082 & 0.1210 & 0.1105\end{array}$

$(0.062)^{*}$

$(0.063)^{*}$

$(0.064)^{*}$

ln (Daily Water Treatment Capacity)

$-0.0542$

0.0066

0.0058

(0.048)

$-0.0605$

$(0.003)^{* *}$

$(0.003)^{*}$

$(0.048)$
-0.0115

(0.048)

(0.067)

$-0.0727$

In (Maximum Daily Water Production)

$(0.047)$

$-0.0157$

(0.049)

(0.047)

(0.046) 


\begin{tabular}{|c|c|c|c|c|}
\hline $\begin{array}{l}\text { Dependent Variable: } \\
\text { In (Monthly Chargers per Ccf) }\end{array}$ & $\begin{array}{l}\frac{\text { Model 1 }}{\text { Estimate }} \\
\text { (Std. Error) }\end{array}$ & $\begin{array}{l}\frac{\text { Model 2 }}{\text { Estimate }} \\
\text { (Std. Error) }\end{array}$ & $\begin{array}{l}\frac{\text { Model 3 }}{\text { Estimate }} \\
\text { (Std. Error) }\end{array}$ & $\begin{array}{l}\frac{\text { Model 4 }}{\text { Estimate }} \\
\text { (Std. Error) }\end{array}$ \\
\hline Ground Water & $\begin{array}{l}-0.0041 \\
(0.001)^{* * *}\end{array}$ & $\begin{array}{l}-0.0040 \\
(0.001)^{* * *}\end{array}$ & $\begin{array}{l}-0.0043 \\
(0.001)^{* * *}\end{array}$ & $\begin{array}{l}-0.0042 \\
(0.001)^{* * *}\end{array}$ \\
\hline Surface Water & $\begin{array}{l}-0.0018 \\
(0.001)^{* *}\end{array}$ & $\begin{array}{l}-0.0018 \\
(0.001)^{* *}\end{array}$ & $\begin{array}{l}-0.0019 \\
(0.001)^{* *}\end{array}$ & $\begin{array}{l}-0.0018 \\
(0.001)^{* *}\end{array}$ \\
\hline Water Loss & $\begin{array}{l}0.0078 \\
(0.003)^{* * *}\end{array}$ & $\begin{array}{l}0.0074 \\
(0.002)^{* * *}\end{array}$ & $\begin{array}{l}0.0071 \\
(0.003)^{* * *}\end{array}$ & $\begin{array}{l}0.0069 \\
(0.003)^{* * *}\end{array}$ \\
\hline LCV Index & $\begin{array}{l}0.0060 \\
(0.003)^{* *}\end{array}$ & $\begin{array}{l}0.0056 \\
(0.003)^{* *}\end{array}$ & $\begin{array}{r}0.0049 \\
(0.003)\end{array}$ & $\begin{array}{r}0.0046 \\
(0.003)\end{array}$ \\
\hline Doctrine of Prior Appropriation (Dummy) & $\begin{array}{l}0.4622 \\
(0.144)^{* * *}\end{array}$ & $\begin{array}{l}0.4517 \\
(0.147)^{* * *}\end{array}$ & & \\
\hline Doctrine of Prior Appropriation (Index) & & & $\begin{array}{l}0.1316 \\
(0.093)\end{array}$ & $\begin{array}{c}0.1282 \\
(0.093)\end{array}$ \\
\hline Middle Atlantic & $\begin{array}{l}0.4054 \\
(0.162)^{* * *}\end{array}$ & $\begin{array}{l}0.3770 \\
(0.165)^{* *}\end{array}$ & $\begin{array}{r}0.1644 \\
(0.142)\end{array}$ & $\begin{array}{l}0.1346 \\
(0.145)\end{array}$ \\
\hline Midwest & $\begin{array}{l}0.0926 \\
(0.132)\end{array}$ & $\begin{array}{r}0.0732 \\
(0.137)\end{array}$ & $\begin{array}{l}-0.0723 \\
(0.123)\end{array}$ & $\begin{array}{l}-0.0884 \\
(0.128)\end{array}$ \\
\hline New England & $\begin{array}{c}0.0961 \\
(0.197)\end{array}$ & $\begin{array}{c}0.0742 \\
(0.203)\end{array}$ & $\begin{array}{l}-0.1294 \\
(0.188)\end{array}$ & $\begin{array}{l}-0.1482 \\
(0.192)\end{array}$ \\
\hline South & $\begin{array}{c}0.3614 \\
(0.160)^{* *}\end{array}$ & $\begin{array}{l}0.3181 \\
(0.163)^{* *}\end{array}$ & $\begin{array}{c}0.0850 \\
(0.122)\end{array}$ & $\begin{array}{c}0.0436 \\
(0.124)\end{array}$ \\
\hline West & $\begin{array}{l}-0.3085 \\
(0.102)^{* * *}\end{array}$ & $\begin{array}{l}-0.3093 \\
(0.104)^{* * *}\end{array}$ & $\begin{array}{l}-0.2895 \\
(0.117)^{* * *}\end{array}$ & $\begin{array}{l}-0.2937 \\
(0.119)^{* * *}\end{array}$ \\
\hline $\mathrm{N}$ & 259 & 259 & 259 & 259 \\
\hline F value & 6.14 & 5.34 & 5.44 & 4.73 \\
\hline Prob $>F$ & 0.000 & 0.000 & 0.000 & 0.000 \\
\hline$R^{2}$ & 0.3361 & 0.3327 & 0.3122 & 0.3103 \\
\hline
\end{tabular}


APPENDIX TABLE 3

District Ownership

Water Rate Regulation

Seasonal Peak Rates

Provision of Other Infrastructure Services

ln (Long-Term Debts)

\section{Model 1}

Estimate

\section{Model 2}

Estimate Estimate

In (Monthly Chargers per Ccf)

$\ln$ (Water Sold)

$(0.464)^{*}$

0.8855

(Std. Error)

(Std. Error)

Increasing Block Rates (Non-Residential)

Bills Combined

$(0.042)$

$(0.493)$

$(0.443)^{* *}$

0.8984

(0.043)

0.0448

$(0.461)$

0.1908

$(0.058)^{* * *}$

0.1961

(0.044)

0.0437

$-0.1650$

$(0.059)^{*}$
-0.1874

0.1999

$(0.045)$

$(0.087)^{*}$

${ }^{-0.1874}$

$0.057)$

0.2049

$-0.2754$

$(0.143)^{*}$

$(0.088)^{* * *}$

$-0.1883$

Government Ownership

$-0.1565$

$(0.145)$

City Ownership

(0.175)

$-0.0296$

(0.188)

$-0.1855$

$(0.095)^{* *}$

$$
\text { (0.174) }
$$

$-0.0891$

$-0.0442$

(0.081)

(0.091)

$-0.0539$

(0.070)

(0.071)

0.0905

0.0800

(0.069)

$\begin{array}{ll}0.0074 & 0.0069 \\ (0.004)^{* *} & (0.004)^{*}\end{array}$

In (Daily Water Treatment Capacity)

$-0.0946$

$-0.0977$

$(0.049)^{* *}$

$(0.048)^{* *}$

$-0.0016$

$(0.050)$

(0.050)

$\begin{array}{cc}-0.1033 & -0.0642 \\ (0.084) & (0.091) \\ -0.0481 & -0.0585 \\ (0.069) & (0.070) \\ 0.0857 & 0.0766 \\ (0.070) & (0.069) \\ 0.0070 & 0.0066 \\ (0.004)^{*} & (0.004)^{*} \\ -0.1074 & -0.1099 \\ (0.048)^{* *} & (0.049)^{* *} \\ -0.0070 & -0.0052 \\ (0.051) & (0.051)\end{array}$

$-0.1690$

(0.171)

$-0.0497$

(0.184)

-0.1930
$(0.171)$

(171)

$-0.0642$

$-0.0585$

$0.070)$

0.0066

In (Maximum Daily Water Production)

(0.051) 


\begin{tabular}{|c|c|c|c|c|}
\hline $\begin{array}{l}\text { Dependent Variable: } \\
\text { In (Monthly Chargers per Ccf) }\end{array}$ & $\begin{array}{l}\frac{\text { Model 1 }}{\text { Estimate }} \\
\text { (Std. Error) }\end{array}$ & $\begin{array}{l}\frac{\text { Model } 2}{\text { Estimate }} \\
\text { (Std. Error) }\end{array}$ & $\begin{array}{l}\text { Model 3 } \\
\text { Estimate } \\
\text { (Std. Error) }\end{array}$ & $\begin{array}{c}\text { Model } 4 \\
\text { Estimate } \\
\text { (Std. Error) }\end{array}$ \\
\hline Ground Water & $\begin{array}{l}-0.0050 \\
(0.001)^{* * *}\end{array}$ & $\begin{array}{l}-0.0050 \\
(0.001)^{* * *}\end{array}$ & $\begin{array}{l}-0.0053 \\
(0.001)^{* * *}\end{array}$ & $\begin{array}{l}-0.0053 \\
(0.001)^{* * *}\end{array}$ \\
\hline Surface Water & $\begin{array}{l}-0.0024 \\
(0.001)^{* * *}\end{array}$ & $\begin{array}{l}-0.0022 \\
(0.001)^{* *}\end{array}$ & $\begin{array}{l}-0.0025 \\
(0.001)^{* * *}\end{array}$ & $\begin{array}{l}-0.0024 \\
(0.001)^{* * *}\end{array}$ \\
\hline Water Loss & $\begin{array}{c}0.0058 \\
(0.004)\end{array}$ & $\begin{array}{c}0.0052 \\
(0.004)\end{array}$ & $\begin{array}{c}0.0055 \\
(0.004)\end{array}$ & $\begin{array}{r}0.0051 \\
(0.004)\end{array}$ \\
\hline LCV Index & $\begin{array}{l}0.0081 \\
(0.003)^{* * *}\end{array}$ & $\begin{array}{l}0.0081 \\
(0.003)^{* * *}\end{array}$ & $\begin{array}{l}0.0092 \\
(0.003)^{* * *}\end{array}$ & $\begin{array}{l}0.0092 \\
(0.003)^{* * *}\end{array}$ \\
\hline Doctrine of Prior Appropriation (Dummy) & $\begin{array}{c}0.3088 \\
(0.174)^{*}\end{array}$ & $\begin{array}{c}0.3027 \\
(0.179)^{*}\end{array}$ & & \\
\hline Doctrine of Prior Appropriation (Index) & & & $\begin{array}{l}0.1818 \\
(0.090)^{* *}\end{array}$ & $\begin{array}{l}0.1786 \\
(0.091)^{* *}\end{array}$ \\
\hline Middle Atlantic & $\begin{array}{c}0.0634 \\
(0.209)\end{array}$ & $\begin{array}{c}0.0496 \\
(0.213)\end{array}$ & $\begin{array}{l}-0.0503 \\
(0.176)\end{array}$ & $\begin{array}{l}-0.0646 \\
(0.176)\end{array}$ \\
\hline Midwest & $\begin{array}{l}-0.1126 \\
(0.178)\end{array}$ & $\begin{array}{l}-0.1340 \\
(0.183)\end{array}$ & $\begin{array}{l}-0.1861 \\
(0.146)\end{array}$ & $\begin{array}{l}-0.2057 \\
(0.148)\end{array}$ \\
\hline New England & $\begin{array}{l}-0.2117 \\
(0.228)\end{array}$ & $\begin{array}{l}-0.2300 \\
(0.234)\end{array}$ & $\begin{array}{l}-0.3445 \\
(0.205)^{*}\end{array}$ & $\begin{array}{l}-0.3607 \\
(0.208)^{*}\end{array}$ \\
\hline South & $\begin{array}{c}0.1480 \\
(0.188)\end{array}$ & $\begin{array}{c}0.1208 \\
(0.197)\end{array}$ & $\begin{array}{c}0.0571 \\
(0.133)\end{array}$ & $\begin{array}{c}0.0314 \\
(0.138)\end{array}$ \\
\hline West & $\begin{array}{l}-0.3970 \\
(0.116)^{* * *}\end{array}$ & $\begin{array}{l}-0.3923 \\
(0.118)^{* * *}\end{array}$ & $\begin{array}{l}-0.4301 \\
(0.123)^{* * *}\end{array}$ & $\begin{array}{l}-0.4267 \\
(0.124)^{* * *}\end{array}$ \\
\hline $\mathrm{N}$ & 259 & 259 & 259 & 259 \\
\hline F value & 4.39 & 4.21 & 4.32 & 4.11 \\
\hline Prob $>$ F & 0.000 & 0.000 & 0.000 & 0.000 \\
\hline 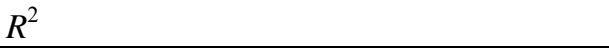 & 0.2816 & 0.2835 & 0.2801 & 0.2822 \\
\hline
\end{tabular}


APPENDIX TABLE 4

District Ownership

Water Rate Regulation

Seasonal Peak Rates

Provision of Other Infrastructure Services

ln (Long-Term Debts)

\section{Model 1}

Estimate

Model 2

Estimate

$\frac{\text { Model } 3}{\text { Mstimate }} \quad \frac{\text { Model } 4}{\text { Estimate }}$

In (Monthly Chargers per Ccf)

(Std. Error) (Std.

ln (Water Sold)

$(0.532)^{* * *}$

$\begin{array}{lcc}1.7015^{* * *} & 1.6913^{* * *} & 1.7412^{* * *}\end{array}$

$(0.546)^{* * *}$

$(0.538)^{* * *}$

$(0.541)^{* * *}$

Increasing Block Rates (Non-Residential)

$0.058)$

$(0.060)$

$-0.0476$

$-0.0544$

Bills Combined

$0.064)$

0.2843

0.2858

$-0.2137$

$-0.2003$

$(0.063)$
-0.2175

0.2941

$(0.081)^{* * *}$

$(0.094)^{* *}$

${ }^{-0.2175}$

$0.063)$

$-0.4051$

City Ownership

$-0.3391$

$(0.174)^{* *}$

$(0.174)^{* *}$

$0.198)$

$-0.2804$

$(0.169)^{*}$

$-0.2565$

$-0.2050$

(0.101)

$(0.101)^{* *}$

$-0.1475$

$(0.076)^{* *}$

0.1511

$(0.069)^{* *}$

0.0101

$(0.004)^{* * *}$

$-0.0295$

(0.059)

$-0.2719$

$(0.102)^{* * *}$

$-0.2006$

$(0.075)$

$-0.1289$

(0.074)

0.1567

$(0.072)^{*}$

0.0104

$(0.004)^{* * *}$

$-0.0387$

$(0.059)$
0.0076

$-0.3522$

$(0.171)^{* *}$

$-0.1213$

(0.195)

$-0.2885$

(0.167)

0.0108

0.0144

$-0.2234$

$-0.0267$

(0.041)

(0.042)

$-0.1509$

$(0.075)^{* *}$

0.1490

$(0.070)^{* *}$

0.0098

$(0.004)^{* *}$

$-0.0397$

(0.060)

$(0.041) \quad(0.04$ 


\begin{tabular}{|c|c|c|c|c|}
\hline $\begin{array}{l}\text { Dependent Variable: } \\
\text { In (Monthly Chargers per Ccf) }\end{array}$ & $\begin{array}{l}\frac{\text { Model 1 }}{\text { Estimate }} \\
\text { (Std. Error) }\end{array}$ & $\begin{array}{l}\frac{\text { Model } 2}{\text { Estimate }} \\
\text { (Std. Error) }\end{array}$ & $\begin{array}{l}\frac{\text { Model } 3}{\text { Estimate }} \\
\text { (Std. Error) }\end{array}$ & $\begin{array}{l}\text { Model } 4 \\
\text { Estimate } \\
\text { (Std. Error) }\end{array}$ \\
\hline Ground Water & $\begin{array}{l}-0.0057 \\
(0.001)^{* * *}\end{array}$ & $\begin{array}{l}-0.0056 \\
(0.001)^{* * *}\end{array}$ & $\begin{array}{l}-0.0060 \\
(0.001)^{* * *}\end{array}$ & $\begin{array}{l}-0.0059 \\
(0.001)^{* * *}\end{array}$ \\
\hline Surface Water & $\begin{array}{l}-0.0028 \\
(0.001)^{* * *}\end{array}$ & $\begin{array}{l}-0.0027 \\
(0.001)^{* * *}\end{array}$ & $\begin{array}{l}-0.0030 \\
(0.001)^{* * *}\end{array}$ & $\begin{array}{l}-0.0028 \\
(0.001)^{* * *}\end{array}$ \\
\hline Water Loss & $\begin{array}{l}-0.0029 \\
(0.004)\end{array}$ & $\begin{array}{l}-0.0036 \\
(0.004)\end{array}$ & $\begin{array}{l}-0.0032 \\
(0.004)\end{array}$ & $\begin{array}{l}-0.0038 \\
(0.004)\end{array}$ \\
\hline LCV Index & $\begin{array}{c}0.0084 \\
(0.003)^{* *}\end{array}$ & $\begin{array}{c}0.0080 \\
(0.003)^{* *}\end{array}$ & $\begin{array}{c}0.0091 \\
(0.004)^{* *}\end{array}$ & $\begin{array}{c}0.0087 \\
(0.004)^{* *}\end{array}$ \\
\hline Doctrine of Prior Appropriation (Dummy) & $\begin{array}{c}0.3074 \\
(0.173)^{*}\end{array}$ & $\begin{array}{c}0.2696 \\
(0.180)\end{array}$ & & \\
\hline Doctrine of Prior Appropriation (Index) & & & $\begin{array}{c}0.1620 \\
(0.098)^{*}\end{array}$ & $\begin{array}{c}0.1449 \\
(0.098)\end{array}$ \\
\hline Middle Atlantic & $\begin{array}{c}0.1063 \\
(0.211)\end{array}$ & $\begin{array}{c}0.0340 \\
(0.221)\end{array}$ & $\begin{array}{l}-0.0174 \\
(0.180)\end{array}$ & $\begin{array}{l}-0.0760 \\
(0.184)\end{array}$ \\
\hline Midwest & $\begin{array}{l}-0.2347 \\
(0.176)\end{array}$ & $\begin{array}{l}-0.2754 \\
(0.183)\end{array}$ & $\begin{array}{l}-0.3167 \\
(0.148)^{* *}\end{array}$ & $\begin{array}{l}-0.3458 \\
(0.152)^{* *}\end{array}$ \\
\hline New England & $\begin{array}{l}-0.3169 \\
(0.249)\end{array}$ & $\begin{array}{l}-0.3653 \\
(0.258)\end{array}$ & $\begin{array}{l}-0.4541 \\
(0.232)^{* *}\end{array}$ & $\begin{array}{l}-0.4856 \\
(0.236)^{* *}\end{array}$ \\
\hline South & $\begin{array}{c}0.0272 \\
(0.188)\end{array}$ & $\begin{array}{l}-0.0668 \\
(0.201)\end{array}$ & $\begin{array}{l}-0.0829 \\
(0.140)\end{array}$ & $\begin{array}{l}-0.1614 \\
(0.150)\end{array}$ \\
\hline West & $\begin{array}{l}-0.4058 \\
(0.125)^{* * *}\end{array}$ & $\begin{array}{l}-0.4090 \\
(0.126)^{* * *}\end{array}$ & $\begin{array}{l}-0.4297 \\
(0.133)^{* * *}\end{array}$ & $\begin{array}{l}-0.4329 \\
(0.134)^{* * *}\end{array}$ \\
\hline $\mathrm{N}$ & 259 & 259 & 259 & 259 \\
\hline F value & 7.19 & 6.72 & 6.80 & 6.44 \\
\hline Prob $>F$ & 0.000 & 0.000 & 0.000 & 0.000 \\
\hline 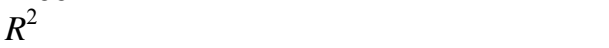 & 0.3375 & 0.3459 & 0.3348 & 0.3441 \\
\hline
\end{tabular}

